Article

\title{
Synthesis and Crystal Chemistry of Octahedral Rhodium(III) Chloroamines ${ }^{\dagger}$
}

\author{
Kirill V. Yusenko ${ }^{1, *(\mathbb{D}}$, Aleksandr S. Sukhikh ${ }^{2,3}$, , Werner Kraus $^{1}$ and Sergey A. Gromilov ${ }^{2,3}$ \\ 1 BAM Federal Institute for Materials Research and Testing, Richard-Willstätter Str. 11, D-12489 Berlin, \\ Germany; w.kraus@bam.de \\ 2 Nikolaev Institute of Inorganic Chemistry, Lavrentiev ave. 3, 630090 Novosibirsk, Russia; \\ a_sukhikh@niic.nsc.ru (A.S.S.); grom@niic.nsc.ru (S.A.G.) \\ 3 Novosibirsk State University, Pirogova str. 2, 630090 Novosibirsk, Russia \\ * Correspondence: kirill.yusenko@bam.de; Tel.: +49-30-8104-5846 \\ + Dedicated to Prof. Dr. Anatoly V. Belyaev on the Occasion of his 80th Birthday.
}

Academic Editor: Barbara Modec

Received: 16 January 2020; Accepted: 10 February 2020; Published: 11 February 2020

check for updates

\begin{abstract}
Rhodium(III) octahedral complexes with amine and chloride ligands are the most common starting compounds for preparing catalytically active rhodium(I) and rhodium(III) species. Despite intensive study during the last 100 years, synthesis and crystal structures of rhodium(III) complexes were described only briefly. Some $\left[\mathrm{RhCl}_{x}\left(\mathrm{NH}_{3}\right)_{6-x}\right]$ compounds are still unknown. In this study, available information about synthetic protocols and the crystal structures of possible $\left[\mathrm{RhCl}_{x}\left(\mathrm{NH}_{3}\right)_{6-x}\right]$ octahedral species are summarized and critically analyzed. Unknown crystal structures of $\left(\mathrm{NH}_{4}\right)_{2}\left[\mathrm{Rh}\left(\mathrm{NH}_{3}\right) \mathrm{Cl}_{5}\right]$, trans- $\left[\mathrm{Rh}\left(\mathrm{NH}_{3}\right)_{4} \mathrm{Cl}_{2}\right] \mathrm{Cl} \cdot \mathrm{H}_{2} \mathrm{O}$, and cis- $\left[\mathrm{Rh}\left(\mathrm{NH}_{3}\right)_{4} \mathrm{Cl}_{2}\right] \mathrm{Cl}$ are reported based on high quality single crystal X-ray diffraction data. The crystal structure of $\left[\mathrm{Rh}\left(\mathrm{NH}_{3}\right)_{5} \mathrm{Cl}\right] \mathrm{Cl}_{2}$ was redetermined. All available crystal structures with octahedral complexes $\left[\mathrm{RhCl}_{x}\left(\mathrm{NH}_{3}\right)_{6-x}\right]$ were analyzed in terms of their packings and pseudo-translational sublattices. Pseudo-translation lattices suggest face-centered cubic and hexagonal closed-packed sub-cells, where Rh atoms occupy nearly ideal lattices.
\end{abstract}

Keywords: rhodium complexes; ligand substitution; crystal structure; pseudo-translational sublattices

\section{Introduction}

Rhodium(III) coordination compounds play an important role in Rh chemistry. Many Rh(III) species are suggested to be active homogeneous catalysts for practically important reactions. Rhodium organometallic chemistry has been investigated in details to support progress in chemical technology and catalysis [1,2]. Rhodium amines and acidocomplexes such as chlorides, nitrites, and sulfates play a fundamental role as intermediates in rhodium refinery from other platinum group metals (especially iridium). Rhodium(III) has an octahedral coordination, and as a result, substitution in its amine-coordinated compounds is kinetically difficult. Despite intensive research, not all theoretically possible rhodium(III) complexes have been isolated and structurally investigated in details, so far. Rhodium(III) coordinated with $\mathrm{Cl}$ and $\mathrm{NH}_{3}$ ligands can form 7 possible types of octahedral species [3]:
i) $\left[\mathrm{RhCl}_{6}\right]^{3-}$;
ii) $\quad\left[\mathrm{Rh}\left(\mathrm{NH}_{3}\right) \mathrm{Cl}_{5}\right]^{2-}$;
iii) cis- and trans-[ $\left.\mathrm{Rh}\left(\mathrm{NH}_{3}\right)_{2} \mathrm{Cl}_{4}\right]^{-}$;
iv) fac- and mer-[ $\left.\mathrm{Rh}\left(\mathrm{NH}_{3}\right)_{3} \mathrm{Cl}_{3}\right]$;
v) cis- and trans- $\left[\mathrm{Rh}\left(\mathrm{NH}_{3}\right)_{4} \mathrm{Cl}_{2}\right]^{+}$;
vi) $\left[\mathrm{Rh}\left(\mathrm{NH}_{3}\right)_{5} \mathrm{Cl}\right]^{2+}$; 
vii) $\left[\mathrm{Rh}\left(\mathrm{NH}_{3}\right)_{6}\right]^{3+}$.

Among all possible compounds, salts with $\left[\mathrm{RhCl}_{6}\right]^{3-}$ and $\left[\mathrm{Rh}\left(\mathrm{NH}_{3}\right)_{5} \mathrm{Cl}\right]^{2+}$ are the most common and have been investigated in great details. $\left[\mathrm{Rh}\left(\mathrm{NH}_{3}\right)_{5} \mathrm{Cl}\right] \mathrm{Cl}_{2}$ seems to be the first investigated $\mathrm{Rh}$ (III) coordination compound [4] and was one of the first $\mathrm{Rh}(\mathrm{III})$ compound that was structurally characterized [5]. Crystal structures of fac- $\left[\mathrm{Rh}\left(\mathrm{NH}_{3}\right)_{3} \mathrm{Cl}_{3}\right]$ and diverse salts with $\left[\mathrm{Rh}\left(\mathrm{NH}_{3}\right)_{6}\right]^{3+}$ cations, as well as the first complexes with known anions $\left[\mathrm{Rh}\left(\mathrm{NH}_{3}\right) \mathrm{Cl}_{5}\right]^{2-}$ and cis- $\left[\mathrm{Rh}\left(\mathrm{NH}_{3}\right)_{2} \mathrm{Cl}_{4}\right]^{-}$were just recently reported [6-8]. No previous study have looked at the crystal structures of complexes with known cis- $\left[\mathrm{Rh}\left(\mathrm{NH}_{3}\right)_{4} \mathrm{Cl}_{2}\right]^{+}$. Synthesis and properties of trans- $\left[\mathrm{Rh}\left(\mathrm{NH}_{3}\right)_{2} \mathrm{Cl}_{4}\right]^{-}$as well as mer- $\left[\mathrm{Rh}\left(\mathrm{NH}_{3}\right)_{3} \mathrm{Cl}_{3}\right]$ have never been reported in the literature. As soon as the crystal structures of $\mathrm{Rh}(\mathrm{III})$ chloroamines were investigated during the past 80 years and briefly described in several sporadic publications, there was a need to perform a critical analysis of available experimental data and formulate general trends in their synthesis and crystal structures, especially to understand their packings in the context of stereochemistry.

Among the coordination compounds of transition metals with "simple" inorganic ligands, only crystal structures of $\left[\mathrm{Pt}\left(\mathrm{NH}_{3}\right)_{x} \mathrm{Cl}_{1-x}\right]$ complexes containing $\mathrm{Pt}(\mathrm{IV})$ were systematically investigated and assessed from the crystallographic points of view [9]. At that time (70 years ago), all possible $\left[\mathrm{Pt}\left(\mathrm{NH}_{3}\right)_{x} \mathrm{Cl}_{1-x}\right]$ complexes were synthesized, but not all crystal structures were known. Nevertheless, there were no efforts made to complete the $\mathrm{Pt}(\mathrm{IV})$ series or extend our knowledge about crystallography of coordination compounds of transition metals through a systematic investigation of other transition metals. Series of coordination compounds of other metals were investigated sporadically. In a later review [10], authors postulated the following. The main attention so far was paid to solve crystal structures of coordination compounds with organic ligands. At the same time, many crystal structures of coordination compounds with "simple" inorganic ligands were still unknown. Nevertheless, such complexes are important intermediates and target compounds that might be used as good models in understanding chemical reactions and processes for investigation of the chemical and structural aspects of coordination chemistry. The main idea of the current study was to fill this gap in experimental data regarding $\mathrm{Rh}(\mathrm{III})$ chloroamine complexes, obtain missing crystallographic information, and critically analyze existing experimental data on the synthetic procedures and crystal structures of $\mathrm{Rh}(\mathrm{III})$ chloroamines. The main goal was to understand the general trends in the $\mathrm{Rh}$ (III) crystal chemistry, as well as analyze the available crystal structures in terms of their packings and pseudo-translational sublattices. New crystal structures of $\left(\mathrm{NH}_{4}\right)_{2}\left[\mathrm{Rh}\left(\mathrm{NH}_{3}\right) \mathrm{Cl}_{5}\right]$, trans- $\left[\mathrm{Rh}\left(\mathrm{NH}_{3}\right)_{4} \mathrm{Cl}_{2}\right] \mathrm{Cl} \cdot \mathrm{H}_{2} \mathrm{O}$ and cis- $-\left[\mathrm{Rh}\left(\mathrm{NH}_{3}\right)_{4} \mathrm{Cl}_{2}\right] \mathrm{Cl}$ were solved and refined, and a crystal structure of the Claus salt, $\left[\mathrm{Rh}\left(\mathrm{NH}_{3}\right)_{5} \mathrm{Cl}_{\mathrm{Cl}} \mathrm{Cl}_{2}\right.$ was re-determined as well, based on high-quality single crystal $\mathrm{X}$-ray diffraction data.

\section{Review of the Available Synthetic Routines to Access Rh(III) Chloroamines}

$\mathrm{RhCl}_{3} \cdot x \mathrm{H}_{2} \mathrm{O}$ is traditionally used as a starting chemical for the preparation of most $\mathrm{Rh}(\mathrm{III})$ complexes. All $\mathrm{Rh}(\mathrm{III})$ chloroamines could be in principle prepared by a reaction of $\mathrm{RhCl}_{3} \cdot x \mathrm{H}_{2} \mathrm{O}$ with ammonia or ammonium chloride. Nevertheless, not all compounds are easily accessible due to the fast substitution of the first ligands in $\left[\mathrm{RhCl}_{6}\right]^{3-}$ and $\left[\mathrm{Rh}\left(\mathrm{NH}_{3}\right) \mathrm{Cl}_{5}\right]^{2-}$ and difficulties in the substitution of the last $\mathrm{Cl}$-ligand in $\left[\mathrm{Rh}\left(\mathrm{NH}_{3}\right)_{5} \mathrm{Cl}\right]^{2+}$. High interest of the $\left[\mathrm{Rh}\left(\mathrm{NH}_{3}\right)_{5} \mathrm{Cl}\right]^{2+}$ species indicates its practical importance for $\mathrm{Rh}(\mathrm{III})$ coordination chemistry. Schematically, synthesis of various rhodium(III) chloroamines are summarized in Scheme 1.

In general, ammonia substitution in $\mathrm{Rh}(\mathrm{III})$ is a relatively slow process and can be controlled by $\mathrm{pH}$. $\mathrm{pH}$ control can be achieved using buffer solutions such as $\left(\mathrm{NH}_{4} \mathrm{Cl}+\mathrm{CH}_{3} \mathrm{COONH}_{4}\right)$ or $\left(\mathrm{NH}_{4} \mathrm{Cl}\right.$ $\left.+\mathrm{NH}_{4} \mathrm{CO}_{3}\right)$, with a $\mathrm{pH} 7$ and $\left(\mathrm{NH}_{4} \mathrm{Cl}+\mathrm{NH}_{3}\right)$ with a $\mathrm{pH}$ 8.2. $\left(\mathrm{NH}_{4}\right)_{2}\left[\mathrm{Rh}\left(\mathrm{NH}_{3}\right) \mathrm{Cl}_{5}\right]$ first forms at neutral $\mathrm{pH}$. In more basic media, $\left[\mathrm{Rh}\left(\mathrm{NH}_{3}\right)_{3} \mathrm{Cl}_{3}\right]$ and $\left[\mathrm{Rh}\left(\mathrm{NH}_{3}\right)_{4} \mathrm{Cl}_{2}\right] \mathrm{Cl}$ as well as $\left[\mathrm{Rh}\left(\mathrm{NH}_{3}\right)_{5} \mathrm{Cl}\right] \mathrm{Cl}_{2}$ can be isolated [11]. Due to the low trans-effect of coordinated ammonia, in comparison to $\mathrm{Cl}^{-}$and $\mathrm{NO}_{2}{ }^{-}$, reaction of $\left[\mathrm{RhCl}_{6}\right]^{3-}$ or $\left[\mathrm{Rh}\left(\mathrm{NO}_{2}\right)_{6}\right]^{3-}$ with ammonia, results in a formation of cis- $\left[\mathrm{Rh}\left(\mathrm{NH}_{3}\right)_{2} \mathrm{Cl}_{4}\right]^{-}$ and cis- $\left[\mathrm{Rh}\left(\mathrm{NH}_{3}\right)_{2}\left(\mathrm{NO}_{2}\right)_{4}\right]^{-}$, respectively [3]. Further nitration should result in a formation of 
fac- $\left[\mathrm{Rh}\left(\mathrm{NH}_{3}\right)_{3} \mathrm{Cl}_{3}\right]$ and fac-[ $\left.\mathrm{Rh}\left(\mathrm{NH}_{3}\right)_{3}\left(\mathrm{NO}_{2}\right)_{3}\right]$, which was confirmed experimentally [6-8]. Due to the high stability of $\left[\mathrm{Rh}\left(\mathrm{NH}_{3}\right)_{5} \mathrm{Cl}\right] \mathrm{Cl}_{2}$, its deamination cannot be performed to access mer- $\left[\mathrm{Rh}\left(\mathrm{NH}_{3}\right)_{3} \mathrm{Cl}_{3}\right]$. Only trans $-\left[\mathrm{Rh}\left(\mathrm{NH}_{3}\right)_{2} \mathrm{Cl}_{4}\right]^{-}$can be prepared from $\left[\mathrm{Rh}\left(\mathrm{NH}_{3}\right)_{5} \mathrm{Cl} \mathrm{Cl}_{2}\right.$, using reactions with reducing agents (see synthesis 2.5 below). As far as we know, synthesis and properties of trans- $\left[\mathrm{Rh}\left(\mathrm{NH}_{3}\right)_{2} \mathrm{Cl}_{4}\right]^{-}$ salts as well as mer- $\left[\mathrm{Rh}\left(\mathrm{NH}_{3}\right)_{3} \mathrm{Cl}_{3}\right]$ were not described in the literature. Reaction with bidentate $\mathrm{C}_{2} \mathrm{O}_{4}{ }^{2-}$ was successfully applied for the substitution of amine- to acido-ligand: $\left[\mathrm{Rh}\left(\mathrm{NH}_{3}\right)_{5} \mathrm{Cl}\right]^{2+}+\mathrm{C}_{2} \mathrm{O}_{4}{ }^{2-}$ $\rightarrow\left[\mathrm{Rh}\left(\mathrm{NH}_{3}\right)_{4}\left(\mathrm{C}_{2} \mathrm{O}_{4}\right)\right]^{+}+\mathrm{Cl}^{-}+\mathrm{NH}_{3}$ and further $\left[\mathrm{Rh}\left(\mathrm{NH}_{3}\right)_{4}\left(\mathrm{C}_{2} \mathrm{O}_{4}\right)\right]^{+}+2 \mathrm{Cl}^{-} \rightarrow$ cis- $\left[\mathrm{Rh}\left(\mathrm{NH}_{3}\right)_{4} \mathrm{Cl}_{2}\right]^{+}$ $+\mathrm{C}_{2} \mathrm{O}_{4}{ }^{2-}$. trans- $\left[\mathrm{Rh}\left(\mathrm{NH}_{3}\right)_{4} \mathrm{Cl}_{2}\right]^{+}$has been obtained by a direct reaction of $\left[\mathrm{RhCl}_{6}\right]^{3-}$ with ammonia at high $\mathrm{pH}$. It seems that, $\left[\mathrm{Rh}\left(\mathrm{NH}_{3}\right)_{5} \mathrm{Cl}\right] \mathrm{Cl}_{2}$ is the most stable $\mathrm{Rh}(\mathrm{III})$ ammine complex and it can be prepared by deep amination of any rhodium compounds. The sixth chloride-ligand cannot be easily substituted and $\left[\mathrm{Rh}\left(\mathrm{NH}_{3}\right)_{6}\right] \mathrm{Cl}_{3}$ can only be prepared in an autoclave using concentrated water ammonia as a reaction medium. cis- $\left[\mathrm{Rh}\left(\mathrm{NH}_{3}\right)_{4} \mathrm{Cl}_{2}\right] \mathrm{Cl}$ has been synthetized by Hancock, using oxalate substitution [12] but its crystal structure was unknown.

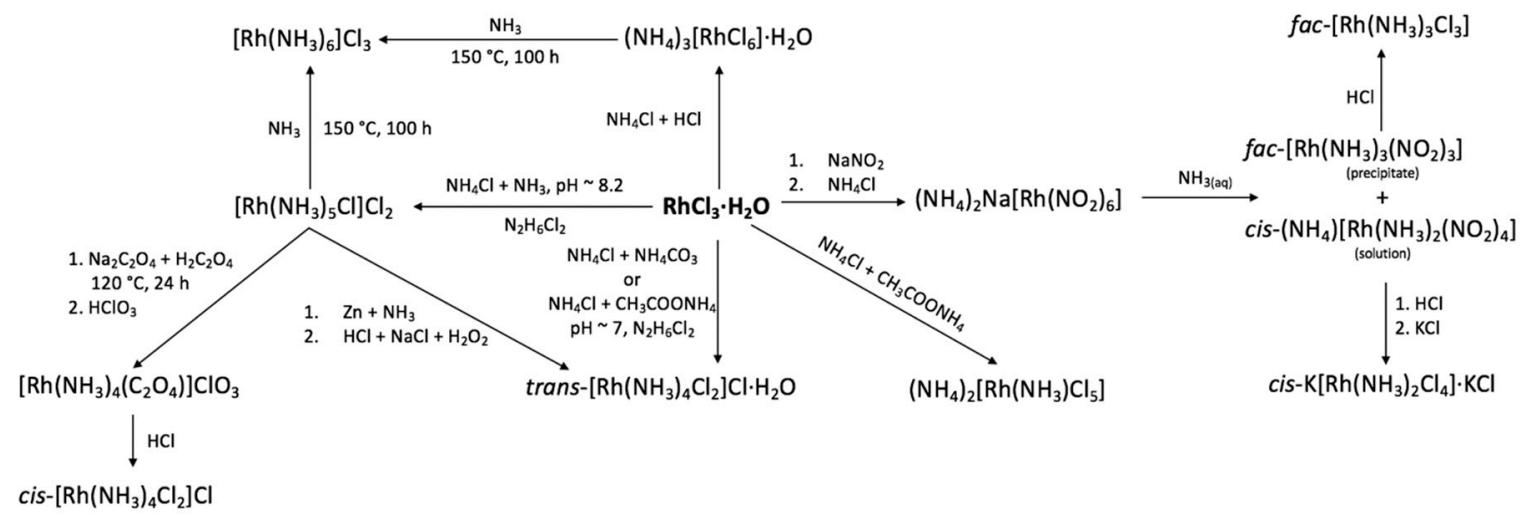

Scheme 1. Synthetic pathways to access Rh(III) chloroamines.

Reducing agents such as ethanol, Zn-dust, and especially hydrazinium salts speed up a ligand's substitution in $\mathrm{Rh}(\mathrm{III})$ complexes, due to a possible formation of highly reactive $\mathrm{Rh}(\mathrm{I})$ intermediates. Such catalytic reaction has been utilized to prepare trans- $\left[\mathrm{Rh}\left(\mathrm{NH}_{3}\right)_{4} \mathrm{Cl}_{2}\right] \mathrm{Cl}$ and $\left[\mathrm{Rh}\left(\mathrm{NH}_{3}\right)_{5} \mathrm{Cl}\right] \mathrm{Cl}_{2}$ with high yields [11]. High stability of the Rh(III) complexes with nitrito-ligand can be used to access $\mathrm{Rh}(\mathrm{III})$ chloroamines, which can be can be obtained using a reaction of $\left[\mathrm{Rh}\left(\mathrm{NO}_{2}\right)_{6}\right]^{3-}$ with ammonia and further with $\mathrm{HCl}[8,13,14]$. In particular, such reaction can be utilized for preparation of fac- $\left[\mathrm{Rh}\left(\mathrm{NH}_{3}\right)_{3} \mathrm{Cl}_{3}\right]$, cis- $\left[\mathrm{Rh}\left(\mathrm{NH}_{3}\right)_{2} \mathrm{Cl}_{4}\right]^{-}$, and $\left[\mathrm{Rh}\left(\mathrm{NH}_{3}\right) \mathrm{Cl}_{5}\right]^{2-}$. Complicity of synthesis of cis- $\left[\mathrm{Rh}\left(\mathrm{NH}_{3}\right)_{2} \mathrm{Cl}_{4}\right]^{-}$salts can be explained by their relatively high solubility, in comparison with other $\mathrm{Rh}(\mathrm{III})$ chloroamines. Nevertheless, it seems that, cis- $\left[\mathrm{Rh}\left(\mathrm{NH}_{3}\right)_{2} \mathrm{Cl}_{4}\right]^{-}$has a high stability in solid-state and in solution. $\left[\mathrm{Rh}\left(\mathrm{NH}_{3}\right)_{6}\right] \mathrm{Cl}_{3}$ can be isolated from hydrothermal reaction in concentrated ammonia solutions.

Available synthetic protocols for known rhodium(III) chloroamines are briefly summarized below.

\subsection{Ammonium Hexachlororhodate(III)}

$\left(\mathrm{NH}_{4}\right)_{3}\left[\mathrm{RhCl}_{6}\right] \cdot \mathrm{H}_{2} \mathrm{O}$ can be isolated by slow evaporation of a $3 \mathrm{M} \mathrm{HCl}$ solution containing the stoichiometric amounts of $\mathrm{RhCl}_{3} \cdot x \mathrm{H}_{2} \mathrm{O}$ and $\mathrm{NH}_{4} \mathrm{Cl}$, with quantitative yield [15]; alternatively, according to [16,17], $\left(\mathrm{NH}_{4}\right)_{3}\left[\mathrm{RhCl}_{6}\right] \cdot \mathrm{H}_{2} \mathrm{O}$ can also be prepared by a direct reaction of $\mathrm{H}_{3}\left[\mathrm{RhCl}_{6}\right]$ with $\mathrm{NH}_{4} \mathrm{Cl}$ water solution, or by evaporation of ammonium chloronitrorhodate(III) with $\mathrm{HCl}$ water solution. Water-free $\left(\mathrm{NH}_{4}\right)_{3}\left[\mathrm{RhCl}_{6}\right]$ is prepared by gentle heating of $\left(\mathrm{NH}_{4}\right)_{3}\left[\mathrm{RhCl}_{6}\right] \cdot \mathrm{H}_{2} \mathrm{O}$ in vacuum. For $\left(\mathrm{NH}_{4}\right)_{3}\left[\mathrm{RhCl}_{6}\right] \cdot \mathrm{H}_{2} \mathrm{O}$, the IR-spectrum $\left(\mathrm{cm}^{-1}\right)$ was: 3560, 3471 (broad) $\left(v\left(\mathrm{H}_{2} \mathrm{O}\right)\right) ; 3174$ (strong) $\left(v\left(\mathrm{NH}_{3}\right)\right) ; 1630$ (broad) $\left(\delta_{\mathrm{d}}\left(\mathrm{H}_{2} \mathrm{O}\right)\right) ; 1587\left(\delta_{\mathrm{a}}\left(\mathrm{NH}_{4}{ }^{+}\right)\right) ; 1381\left(\delta_{\mathrm{s}}\left(\mathrm{NH}_{4}{ }^{+}\right)\right) ; 325_{\mathrm{ssh}}, 318_{\mathrm{s}}, 314_{\mathrm{ssh}}(v(\mathrm{RhCl})) ; 205_{\mathrm{m}}$, $196_{\mathrm{sh}}, 185_{\mathrm{m}}(\delta(\mathrm{ClRhCl})) ; 157_{\mathrm{s}}, 145_{\mathrm{s}}$ (lattice) [15]; and the Raman-spectrum $\left(\mathrm{cm}^{-1}\right)$ was: $339\left(v_{1}(\mathrm{RhCl})\right)$; $300\left(v_{2}(\mathrm{RhCl})\right) ; 283(\delta(\mathrm{ClRhCl}))$. 


\subsection{Ammonium Pentachloroaminerhodate(III)}

$\left(\mathrm{NH}_{4}\right)_{2}\left[\mathrm{Rh}\left(\mathrm{NH}_{3}\right) \mathrm{Cl}_{5}\right]$ can be prepared from $\mathrm{Na}_{3}\left[\mathrm{RhCl}_{6}\right]$ or $\mathrm{H}_{3}\left[\mathrm{RhCl}_{6}\right]$ through reaction with a mixture of ammonium chloride and ammonium acetate, in water [18]. In the current study, $\left(\mathrm{NH}_{4}\right)_{2}\left[\mathrm{Rh}\left(\mathrm{NH}_{3}\right) \mathrm{Cl}_{5}\right]$ is prepared from $\left(\mathrm{NH}_{4}\right)_{3}\left[\mathrm{RhCl}_{6}\right] \cdot \mathrm{H}_{2} \mathrm{O} .0 .25 \mathrm{~g}$ of $\left(\mathrm{NH}_{4}\right)_{3}\left[\mathrm{RhCl}_{6}\right] \cdot \mathrm{H}_{2} \mathrm{O}$ and is dissolved in a minimum amount of hot water (several $\mathrm{ml}$ ). A total of $2 \mathrm{~mL}$ of saturated water solution of $\mathrm{NH}_{4} \mathrm{Cl}$ is added. After heating for $5 \mathrm{~min}, 1.2 \mathrm{~mL}$ of ammonium acetate in water is added (ammonium acetate solution is prepared by neutralization of concentrated water ammonia with acetic acid). After heating for $1 \mathrm{~h}$, dark-orange crystals are isolated. An additional portion is isolated by addition of $1 \mathrm{~mL}$ of ammonium acetate solution and evaporation until crystallization of orange needles. After cooling to room temperature, equal amounts of concentrated $\mathrm{NH}_{4} \mathrm{Cl}$ solution is added to the reaction mixture. Precipitate is filtered, washed with diluted $\mathrm{NH}_{4} \mathrm{Cl}$ water solution, and dried in air. Total yield was above $45 \%$. Single crystals for the current single-crystal $X$-ray diffraction study were collected from the first portion. For $\left(\mathrm{NH}_{4}\right)_{2}\left[\mathrm{Rh}\left(\mathrm{NH}_{3}\right) \mathrm{Cl}_{5}\right]$, the IR-spectrum $\left(\mathrm{cm}^{-1}\right)$ was: $3370($ broad $)\left(v\left(\mathrm{NH}_{3}\right)\right)$; 3039 (shoulder) $\left(v_{\mathrm{s}}\left(\mathrm{NH}_{4}^{+}\right)\right) ; 1680$ (shoulder) $\left(\delta_{\mathrm{d}}\left(\mathrm{NH}_{4}^{+}\right)\right) ; 1604,1518\left(\delta_{\mathrm{d}}\left(\mathrm{NH}_{3}\right)\right) ; 1388\left(\delta_{\mathrm{d}}\left(\mathrm{NH}_{4}{ }^{+}\right)\right)$; $1279\left(\delta_{\mathrm{s}}\left(\mathrm{NH}_{3}\right)\right)$; and the Raman-spectrum $\left(\mathrm{cm}^{-1}\right)$ was: $502(v(\mathrm{RhN})) ; 322,305(v(\mathrm{RhCl})) ; 284,218,190$, 130 (skeletal bending).

Crystals of $\mathrm{K}_{2}\left[\mathrm{Rh}\left(\mathrm{NH}_{3}\right) \mathrm{Cl}_{5}\right]$ can be prepared from $\mathrm{K}_{2}\left[\mathrm{Rh}\left(\mathrm{NH}_{3}\right)\left(\mathrm{NO}_{2}\right)_{5}\right] \cdot \mathrm{H}_{2} \mathrm{O}$ [8], by heating in $6 \mathrm{M} \mathrm{HCl}$. After $24 \mathrm{~h}$ of crystallization at room temperature, dark-red crystals are filtered. For $\mathrm{K}_{2}\left[\mathrm{Rh}\left(\mathrm{NH}_{3}\right) \mathrm{Cl}_{5}\right]$, the IR-spectrum $\left(\mathrm{cm}^{-1}\right)$ was: 3310, $3236\left(v\left(\mathrm{NH}_{3}\right)\right)$; 1604, $1519\left(\delta_{\mathrm{a}}\left(\mathrm{NH}_{3}\right)\right)$; $1292\left(\delta_{\mathrm{s}}\left(\mathrm{NH}_{3}\right)\right) ; 516(v(\mathrm{RhN}))[8]$.

\subsection{Potassium cis-Tetrachlorodiamminerhodate(III)}

According to [8,15], cis- $\mathrm{K}\left[\mathrm{Rh}\left(\mathrm{NH}_{3}\right)_{2} \mathrm{Cl}_{4}\right] \cdot \mathrm{KCl}$ can be prepared from $\left(\mathrm{NH}_{4}\right)_{2} \mathrm{Na}\left[\mathrm{Rh}\left(\mathrm{NO}_{2}\right)_{6}\right]$. As the first step, $5 \mathrm{~g}$ of $\mathrm{RhCl}_{3} \cdot x \mathrm{H}_{2} \mathrm{O}$ is nitrated with $12 \mathrm{~g}$ of $\mathrm{NaNO}_{2}$ in $200 \mathrm{~mL}$ water. After heating and filtration, $\left(\mathrm{NH}_{4}\right)_{2} \mathrm{Na}\left[\mathrm{Rh}\left(\mathrm{NO}_{2}\right)_{6}\right]$ is crystallized by addition of saturated $\mathrm{NH}_{4} \mathrm{Cl}$ water solution. Precipitate is filtered and added to ca. $5 \mathrm{~mL}$ of concentrated water solution of $\mathrm{NH}_{3}$, and boiled until its complete dissolution. The solution is cooled and filtrated from the fac $-\left[\mathrm{Rh}\left(\mathrm{NH}_{3}\right)_{3}\left(\mathrm{NO}_{2}\right)_{3}\right]$ precipitate. The residual clear solution is mixed with ca. $10 \mathrm{~g}$ of $\mathrm{KCl}$ and filtered immediately. After 3-4 days at room temperature, crystals of cis- $\mathrm{K}\left[\mathrm{Rh}\left(\mathrm{NH}_{3}\right)_{2}\left(\mathrm{NO}_{2}\right)_{4}\right]$ are filtered. Both parts, crystals and solution, can be treated with $\mathrm{HCl}$ water solution (1:1). After short heating, yellow-orange solution are obtained; cis- $\mathrm{K}\left[\mathrm{Rh}\left(\mathrm{NH}_{3}\right)_{2} \mathrm{Cl}_{4}\right] \cdot \mathrm{KCl}$ can be crystallized by evaporation of the solution at room temperature [8]. For cis-K $\left[\mathrm{Rh}\left(\mathrm{NH}_{3}\right)_{2} \mathrm{Cl}_{4}\right] \cdot \mathrm{KCl}$, the IR-spectrum $\left(\mathrm{cm}^{-1}\right)$ was: 3283 (strong), 3181 (weak) $\left(v\left(\mathrm{NH}_{3}\right)\right) ; 1604$, $1548\left(\delta_{\mathrm{a}}\left(\mathrm{NH}_{3}\right)\right) ; 1287\left(\delta_{\mathrm{s}}\left(\mathrm{NH}_{3}\right)\right) ; 848,793\left(\rho_{\mathrm{r}}\left(\mathrm{NH}_{3}\right)\right) ; 506(v(\mathrm{RhN}))[8]$.

\subsection{Fac-Trichlorotriaminerhodium(III)}

According to $[6,14]$, fac- $\left[\mathrm{Rh}\left(\mathrm{NH}_{3}\right)_{3} \mathrm{Cl}_{3}\right]$ can be prepared by heating of fac- $\left[\mathrm{Rh}\left(\mathrm{NH}_{3}\right)_{3}\left(\mathrm{NO}_{2}\right)_{3}\right]$ with $\mathrm{HCl}(25 \mathrm{~mL}$ of 1:1 aqueous solution), for $3 \mathrm{~h}$. After cooling the solution to room temperature, a light-yellow powder is isolated with a 91\% yield. The crystalline structure of fac- $\left[\mathrm{Rh}\left(\mathrm{NH}_{3}\right)_{3} \mathrm{Cl}_{3}\right]$ was solved and refined using powder X-ray diffraction data (PXRD). Fac- $\left[\mathrm{Rh}\left(\mathrm{NH}_{3}\right)_{3}\left(\mathrm{NO}_{2}\right)_{3}\right]$ can be prepared according to [19], by reaction of $\mathrm{Na}_{3}\left[\mathrm{Rh}\left(\mathrm{NO}_{2}\right)_{6}\right]$ with sulfanilic acid and ammonia, or alternatively as a precipitate of heating of $\left(\mathrm{NH}_{4}\right)_{2} \mathrm{Na}\left[\mathrm{Rh}\left(\mathrm{NO}_{2}\right)_{6}\right]$ with concentrated ammonia solution (see synthesis of cis-K $\left[\mathrm{Rh}\left(\mathrm{NH}_{3}\right)_{2} \mathrm{Cl}_{4}\right] \cdot \mathrm{KCl}$ above). For fac- $\left[\mathrm{Rh}\left(\mathrm{NH}_{3}\right)_{3} \mathrm{Cl}_{3}\right]$, the IR-spectrum $\left(\mathrm{cm}^{-1}\right)$ was: $1590\left(\delta_{\mathrm{a}}\left(\mathrm{NH}_{3}\right)\right)$; $1318\left(\delta_{\mathrm{s}}\left(\mathrm{NH}_{3}\right)\right) ; 837\left(\rho_{\mathrm{r}}\left(\mathrm{NH}_{3}\right)\right)[6]$.

\subsection{Trans-Dichlorotetraminerhodium(III) Chloride}

Synthesis of trans-[Rh( $\left.\left.\mathrm{NH}_{3}\right)_{4} \mathrm{Cl}_{2}\right] \mathrm{Cl}$ was described by Lebedinskii [3] and later modified by other authors $[11,20,21]$. The method reported by Lebedinskii includes a reaction of $\mathrm{RhCl}_{3} \cdot x \mathrm{H}_{2} \mathrm{O}$ with a water solution of $\mathrm{NH}_{4} \mathrm{Cl}$ and $\left(\mathrm{NH}_{4}\right)_{2} \mathrm{CO}_{3}$. The mixture is heated on a steam bath for $3 \mathrm{~h}$ and cooled to room temperature for crystallization. After crystallization of a golden-yellow powder, the solid 
product is extracted by boiling with $\mathrm{HCl}\left(1: 1\right.$ water solution). $\left[\mathrm{Rh}\left(\mathrm{NH}_{3}\right)_{5} \mathrm{Cl}\right] \mathrm{Cl}_{2}$ is insoluble in $\mathrm{HCl}$ water solution but trans-[Rh( $\left.\left(\mathrm{NH}_{3}\right)_{4} \mathrm{Cl}_{2}\right] \mathrm{Cl}$ can be easily dissolved and further recrystallized from diluted $\mathrm{HNO}_{3}$ water solution as trans- $\left[\mathrm{Rh}\left(\mathrm{NH}_{3}\right)_{4} \mathrm{Cl}_{2}\right]\left(\mathrm{NO}_{3}\right) \cdot \mathrm{H}_{2} \mathrm{O}$ [20].

Later, catalytic reaction with $\mathrm{N}_{2} \mathrm{H}_{6} \mathrm{Cl}_{2}$ was suggested to speed up ammonium substitution and improve the yield of trans- $\left[\mathrm{Rh}\left(\mathrm{NH}_{3}\right)_{4} \mathrm{Cl} 2\right] \mathrm{Cl}$ [9]. Briefly, $\left(\mathrm{NH}_{4}\right)_{3}\left[\mathrm{RhCl}_{6}\right] \cdot \mathrm{H}_{2} \mathrm{O}$ is dissolved in water after addition of $\mathrm{NH}_{4} \mathrm{Cl}$ powder, the mixture is boiled until a complete dissolution of the precipitate. Further addition of the $\mathrm{CH}_{3} \mathrm{COONH}_{4}$ water solution and a few milligrams of $\mathrm{N}_{2} \mathrm{H}_{6} \mathrm{Cl}_{2}$ powder, results in an immediate color change from red to golden-yellow. Additional portions of $\mathrm{CH}_{3} \mathrm{COONH}_{4}$ should be added to the reaction mixture to keep $\mathrm{pH} 7$. After cooling to room temperature, a golden-yellow precipitate is filtered. For recrystallization, the trans- $\left[\mathrm{Rh}\left(\mathrm{NH}_{3}\right)_{4} \mathrm{Cl}_{2}\right] \mathrm{Cl}$ powder is dissolved in hot $\mathrm{HCl}(2: 1)$ and evaporated until crystallization. trans- $\left[\mathrm{Rh}\left(\mathrm{NH}_{3}\right)_{4} \mathrm{Cl}_{2}\right] \mathrm{Cl}$ is dissolved in hot water and recrystallized by addition of $\mathrm{HCl}$ water solution. Yield is above $30 \%$. It should be noted, that authors reported water-free salt [11]; nevertheless, later studies suggested that only trans $-\left[\mathrm{Rh}\left(\mathrm{NH}_{3}\right)_{4} \mathrm{Cl}_{2}\right] \mathrm{Cl} \cdot \mathrm{H}_{2} \mathrm{O}$ can be isolated. Such a catalytic reaction seems to be quite easy and reproducible to access trans- $\left[\mathrm{Rh}\left(\mathrm{NH}_{3}\right)_{4} \mathrm{Cl}_{2}\right] \mathrm{Cl} \cdot \mathrm{H}_{2} \mathrm{O}$ and its derivatives.

Alternatively, according to [21], trans $-\left[\mathrm{Rh}\left(\mathrm{NH}_{3}\right)_{4} \mathrm{Cl}_{2}\right] \mathrm{Cl} \cdot \mathrm{H}_{2} \mathrm{O}$ can by prepared from $\left[\mathrm{Rh}\left(\mathrm{NH}_{3}\right)_{5} \mathrm{Cl}\right] \mathrm{Cl}_{2}$. A mixture of $\left[\mathrm{Rh}\left(\mathrm{NH}_{3}\right)_{5} \mathrm{Cl} \mathrm{Cl}_{2}\right.$ and $\mathrm{Zn}$ dust is heated in a solution of $12 \mathrm{M}$ ammonia and water $(10: 13)$ at $50{ }^{\circ} \mathrm{C}$, for $5 \mathrm{~min}$ with stirring. The resultant mixture is filtered. The pale-yellow solution is cooled in an ice-bath. $\mathrm{pH}$ should be adjusted to $\sim 6-7$ by adding of $12 \mathrm{M}$ $\mathrm{HCl}$. $\mathrm{NaCl}, \mathrm{HCl}$, and $\mathrm{H}_{2} \mathrm{O}_{2}$ are sequentially added. The reaction mixture is rapidly boiled under reflux for $30 \mathrm{~min}$; an orange solution is filtered. The precipitate is washed with $0.1 \mathrm{M} \mathrm{HCl}$ and the solution is kept in a refrigerator, overnight at $5{ }^{\circ} \mathrm{C}$. The orange-yellow crystals are isolated by filtration and further recrystallized from $0.1 \mathrm{M} \mathrm{HCl}\left(50^{\circ} \mathrm{C}\right)$, after addition of $6 \mathrm{M} \mathrm{HCl}$ and cooling; yield is above $70 \%$.

For trans- $\left[\mathrm{Rh}\left(\mathrm{NH}_{3}\right)_{4} \mathrm{Cl}_{2}\right] \mathrm{Cl} \cdot \mathrm{H}_{2} \mathrm{O}$, the IR-spectrum $\left(\mathrm{cm}^{-1}\right)$ was: $3268,3178,3155\left(v\left(\mathrm{NH}_{3}\right)\right) ; 1604$, $1542\left(\delta_{\mathrm{a}}\left(\mathrm{NH}_{3}\right)\right) ; 1298$ (strong) $\left(\delta_{\mathrm{s}}\left(\mathrm{NH}_{3}\right)\right) ; 837,820\left(\rho_{\mathrm{r}}\left(\mathrm{NH}_{3}\right)\right)$; the Raman-spectrum $\left(\mathrm{cm}^{-1}\right)$ was: 491,506 $(v(\mathrm{RhN})) ; 306,320$ (shoulder) $(v(\mathrm{RhCl})) ; 270,259,216,205,187,158,148$ (skeletal bending).

\subsection{Cis-Dichlorotetraminerhodium(III) Chloride}

Cis- $\left[\mathrm{Rh}\left(\mathrm{NH}_{3}\right)_{4} \mathrm{Cl}_{2}\right] \mathrm{Cl}$ can be prepared from $\left[\mathrm{Rh}\left(\mathrm{NH}_{3}\right)_{4}\left(\mathrm{C}_{2} \mathrm{O}_{4}\right)\right] \mathrm{ClO}_{4} \cdot \mathrm{H}_{2} \mathrm{O}$ by boiling it for $1 \mathrm{~min}$, with $6 \mathrm{M} \mathrm{HCl}$ [13]. Bright-yellow solution is cooled in ice for crystallization of bright-yellow crystals. An additional portion can be obtained by addition of methanol. The product can be recrystallized from hot water by addition of $3 \mathrm{M} \mathrm{HCl}$; yield is above $90 \%$. [ Rh( $\left.\left(\mathrm{NH}_{3}\right)_{4}\left(\mathrm{C}_{2} \mathrm{O}_{4}\right)\right] \mathrm{ClO}_{4} \cdot \mathrm{H}_{2} \mathrm{O}$ can be prepared from $\left[\mathrm{Rh}\left(\mathrm{NH}_{3}\right)_{5} \mathrm{Cl}\right] \mathrm{Cl}_{2}$ [13]. A mixture of $\left[\mathrm{Rh}\left(\mathrm{NH}_{3}\right)_{5} \mathrm{Cl}\right] \mathrm{Cl}_{2}(6.8 \mathrm{mmol}), \mathrm{Na}_{2} \mathrm{C}_{2} \mathrm{O}_{4}(6.8 \mathrm{mmol})$, and $\mathrm{H}_{2} \mathrm{C}_{2} \mathrm{O}_{4}(3.4 \mathrm{mmol})$ is dissolved in $70 \mathrm{~mL}$ of water, placed in a stainless steel autoclave, and heated at $120{ }^{\circ} \mathrm{C}$ for $24 \mathrm{~h}$. Solution of $\left[\mathrm{Rh}\left(\mathrm{NH}_{3}\right)_{4}\left(\mathrm{C}_{2} \mathrm{O}_{4}\right)\right]^{+}$is filtered out and cooled to room temperature. Small volume of $70 \% \mathrm{HClO}_{4}$ is added to the solution for a crystallization. Pale-yellow crystals are further purified from hot water by addition of water solution of $\mathrm{LiClO}_{4}$; yield is above $55 \%$.

According to our experience, cis- $\left[\mathrm{Rh}\left(\mathrm{NH}_{3}\right)_{4} \mathrm{Cl}_{2}\right] \mathrm{Cl}$ can be prepared without intermediate crystallization of $\left[\mathrm{Rh}\left(\mathrm{NH}_{3}\right)_{4}\left(\mathrm{C}_{2} \mathrm{O}_{4}\right)\right] \mathrm{ClO}_{4} \cdot \mathrm{H}_{2} \mathrm{O}$. A mixture of $\left[\mathrm{Rh}\left(\mathrm{NH}_{3}\right)_{5} \mathrm{Cl}\right] \mathrm{Cl}_{2}(6.8 \mathrm{mmol}), \mathrm{Na}_{2} \mathrm{C}_{2} \mathrm{O}_{4}$ (6.8 mmol), and $\mathrm{H}_{2} \mathrm{C}_{2} \mathrm{O}_{4}(3.4 \mathrm{mmol})$ is dissolved in $70 \mathrm{~mL}$ of water, placed in a stainless steel autoclave, and heated at $120^{\circ} \mathrm{C}$ for $48 \mathrm{~h}$. the reaction mixture should be heated with $1 \mathrm{~mL}$ of concentrated $\mathrm{HCl}$ water solution. After cooling to room temperature, light-yellow precipitate is filtered. Precipitate contains mainly unreacted $\left[\mathrm{Rh}\left(\mathrm{NH}_{3}\right)_{5} \mathrm{Cl}\right] \mathrm{Cl}_{2}$. A light-orange solution is evaporated for several days on air at room temperature. Orange crystals are contaminated with minimum light-yellow $\left[\mathrm{Rh}\left(\mathrm{NH}_{3}\right)_{5} \mathrm{Cl} \mathrm{Cl}_{2}\right.$ crystals, as well as with large light-yellow needles of an unknown crystal structure and composition. The procedure can be recommended for laboratory synthesis of cis- $\left[\mathrm{Rh}\left(\mathrm{NH}_{3}\right)_{4} \mathrm{Cl}_{2}\right] \mathrm{Cl}$. Nevertheless, for preparation of large amounts of the salt, it should be further optimized.

For cis- $\left[\mathrm{Rh}\left(\mathrm{NH}_{3}\right)_{4} \mathrm{Cl}_{2}\right] \mathrm{Cl}$, the IR-spectrum $\left(\mathrm{cm}^{-1}\right)$ was: $3270,3140\left(v\left(\mathrm{NH}_{3}\right)\right) ; 1600\left(\delta_{\mathrm{a}}\left(\mathrm{NH}_{3}\right)\right) ; 1300$, $1290\left(\delta_{\mathrm{s}}\left(\mathrm{NH}_{3}\right)\right) ; 798,818\left(\rho_{\mathrm{r}}\left(\mathrm{NH}_{3}\right)\right)$. The Raman-spectrum $\left(\mathrm{cm}^{-1}\right)$ was: 489, $506(v(\mathrm{RhN})) ; 305(v(\mathrm{RhCl}))$; 252, 217, 203 (skeletal bending). 


\subsection{Chloropentaminerhodium(III) Chloride (Claus Salt)}

Similar to trans- $\left[\mathrm{Rh}\left(\mathrm{NH}_{3}\right)_{4} \mathrm{Cl}_{2}\right] \mathrm{Cl} \cdot \mathrm{H}_{2} \mathrm{O}$, $\left[\mathrm{Rh}\left(\mathrm{NH}_{3}\right)_{5} \mathrm{Cl}\right] \mathrm{Cl}_{2}$ can be prepared from $\mathrm{RhCl}_{3} \cdot x \mathrm{H}_{2} \mathrm{O}$, with high yield, using hydrazinium salts as catalysts [22,23]. In comparison with the synthesis of trans-[ $\left[\mathrm{Rh}\left(\mathrm{NH}_{3}\right)_{4} \mathrm{Cl}_{2}\right] \mathrm{Cl} \cdot \mathrm{H}_{2} \mathrm{O}$, reaction should be performed in a more basic medium. Briefly, $1 \mathrm{~g}$ of $\mathrm{RhCl}_{3} \cdot x \mathrm{H}_{2} \mathrm{O}$ powder is dissolved in $10 \mathrm{~mL}$ of concentrated $\mathrm{HCl}$ and heated for $0.5 \mathrm{~h}$. After complete dissolution, $10-20 \mathrm{mg}$ of solid $\mathrm{N}_{2} \mathrm{H}_{6} \mathrm{Cl}_{2}$ is added together with $20 \mathrm{~mL}$ of hot ammonia buffer, with pH 8.2. Immediately, the solution turns to light-yellow with a formation of $\left[\mathrm{Rh}\left(\mathrm{NH}_{3}\right)_{5} \mathrm{Cl}\right] \mathrm{Cl}_{2}$ precipitate (precipitate might also contain minor quantities of $\mathrm{Rh},\left[\mathrm{Rh}\left(\mathrm{NH}_{3}\right)_{3} \mathrm{Cl}_{3}\right]$ and trans- $\left.\left[\mathrm{Rh}\left(\mathrm{NH}_{3}\right)_{4} \mathrm{Cl}_{2}\right] \mathrm{Cl}\right)$. The precipitate is filtered and washed from $\left[\mathrm{Rh}\left(\mathrm{NH}_{3}\right)_{4} \mathrm{Cl}_{2}\right] \mathrm{Cl}$ with hot $\mathrm{HCl}$ water solution (2:1). $\left[\mathrm{Rh}\left(\mathrm{NH}_{3}\right)_{5} \mathrm{Cl}\right] \mathrm{Cl}_{2}$ can be purified by dissolution in hot water (insoluble $\mathrm{Rh}$ and $\left[\mathrm{Rh}\left(\mathrm{NH}_{3}\right)_{3} \mathrm{Cl}_{3}\right]$ are left on the filter) and recrystallized by addition of an equal volume of $10 \mathrm{wt}$. \% water solution of $\mathrm{HCl}$. After 2-3 h, light yellow crystals of $\left[\mathrm{Rh}\left(\mathrm{NH}_{3}\right)_{5} \mathrm{Cl}\right] \mathrm{Cl}_{2}$ are filtered and washed with ethanol and dried in air; yield is above $75 \%$. For $\left[\mathrm{Rh}\left(\mathrm{NH}_{3}\right)_{5} \mathrm{Cl}\right] \mathrm{Cl}_{2}, \mathrm{IR}$-spectrum $\left(\mathrm{cm}^{-1}\right)$ : 3288 (strong), 3173 (weak) $\left(v\left(\mathrm{NH}_{3}\right)\right) ; 1559\left(\delta_{\mathrm{a}}\left(\mathrm{NH}_{3}\right)\right)$ was; 1308(strong), 1273(weak) $\left(\delta_{\mathrm{s}}\left(\mathrm{NH}_{3}\right)\right) ; 850\left(\rho_{\mathrm{r}}\left(\mathrm{NH}_{3}\right)\right) ; 492\left(v_{\mathrm{a}}(\mathrm{RhN})\right) ; 275$, $266(\delta(\mathrm{NRhN})) ; 200(v(\mathrm{RhCl})) ; 102 \mathrm{shs}, 96 \mathrm{~s}$ (lattice). The Raman-spectrum $\left(\mathrm{cm}^{-1}\right)$ was: 506, $486(v(\mathrm{RhN}))$; $319(v(\mathrm{RhCl})) ; 266(\pi(\mathrm{RhN})+\delta(\mathrm{NRhN}))[22,24]$.

\subsection{Hexaminerhodium(III) Chloride}

$\left[\mathrm{Rh}\left(\mathrm{NH}_{3}\right)_{6}\right] \mathrm{Cl}_{3}$ can be prepared from $\left[\mathrm{Rh}\left(\mathrm{NH}_{3}\right)_{5} \mathrm{Cl}\right] \mathrm{Cl}_{2}$, according to $[7,23]$. $\left[\mathrm{Rh}\left(\mathrm{NH}_{3}\right)_{5} \mathrm{Cl}_{\mathrm{Cl}} \mathrm{Cl}_{2}\right.$ is heated with concentrated $\mathrm{NH}_{3}$ water solution in a $10-\mathrm{mL}$ Teflon autoclave at $150{ }^{\circ} \mathrm{C}$ for $100 \mathrm{~h}$. After natural cooling, the reaction mixture is washed with water and evaporated in air for several days. Dry colorless powder contains pure $\left[\mathrm{Rh}\left(\mathrm{NH}_{3}\right)_{6}\right] \mathrm{Cl}_{3}$. The procedure is quite general, any other rhodium(III) chloroamines, as well as rhodium(III) chloride can be used to prepare $\left[\mathrm{Rh}\left(\mathrm{NH}_{3}\right)_{6}\right] \mathrm{Cl}_{3}$ with nearly quantitative yield.

For $\left[\mathrm{Rh}\left(\mathrm{NH}_{3}\right)_{6}\right] \mathrm{Cl}_{3}$, the IR-spectrum $\left(\mathrm{cm}^{-1}\right)$ was: 3276 (strong), 3181 (weak) $\left(v\left(\mathrm{NH}_{3}\right)\right) ; 1616$, 1572, $1546\left(\delta_{\mathrm{a}}\left(\mathrm{NH}_{3}\right)\right) ; 1302$ (strong), 1279 (weak) $\left(\delta_{\mathrm{s}}\left(\mathrm{NH}_{3}\right)\right) ; 855,821,755\left(\rho_{\mathrm{r}}\left(\mathrm{NH}_{3}\right)\right) ; 470\left(v_{\mathrm{a}}(\mathrm{RhN})\right) ;$ $310\left(\delta_{\mathrm{a}}(\mathrm{NRhN})\right)$ [7]. The Raman-spectrum $\left(\mathrm{cm}^{-1}\right)$ was: $515\left(v_{\mathrm{s}}(\mathrm{RhN})\right) ; 480\left(v_{\mathrm{a}}(\mathrm{RhN})\right) ; 240(\delta(\mathrm{NRhN}))[25]$.

Protocols 2.7 and 2.8 have been tested many times by several independent research groups and can be considered to be the easiest methods for a preparation of $\left[\mathrm{Rh}\left(\mathrm{NH}_{3}\right)_{5} \mathrm{Cl}_{\mathrm{Cl}} \mathrm{Cl}_{2}\right.$ and $\left[\mathrm{Rh}\left(\mathrm{NH}_{3}\right)_{6}\right] \mathrm{Cl}_{3}$ from various starting materials, including $\mathrm{Rh}(\mathrm{IIII})$ refinery as $\left[\mathrm{Rh}\left(\mathrm{NH}_{3}\right)_{5} \mathrm{Cl}\right] \mathrm{Cl}_{2}$ from mixtures of transition metal chlorides. Both protocols give high yields of pure crystalline products.

\section{Materials and Methods}

For the current study, $\left(\mathrm{NH}_{4}\right)_{2}\left[\mathrm{Rh}\left(\mathrm{NH}_{3}\right) \mathrm{Cl}_{5}\right]$ has been prepared according to [18], starting from $\left(\mathrm{NH}_{4}\right)_{3}\left[\mathrm{RhCl}_{6}\right] \cdot \mathrm{H}_{2} \mathrm{O}$ (see procedure 2.2 above). A total of $0.25 \mathrm{~g}\left(\mathrm{NH}_{4}\right)_{3}\left[\mathrm{RhCl}_{6}\right] \cdot \mathrm{H}_{2} \mathrm{O}$ was dissolved in $5 \mathrm{~mL}$ hot water. A total of $2 \mathrm{~mL}$ of saturated water solution of $\mathrm{NH}_{4} \mathrm{Cl}$ was added. After heating for $5 \mathrm{~min}, 1.2 \mathrm{~mL}$ of ammonium acetate in water was added. After heating for $1 \mathrm{~h}$ and cooling to room temperature, dark-orange crystals were isolated.

Light-orange, plate-shaped, single crystals of trans- $\left[\mathrm{Rh}\left(\mathrm{NH}_{3}\right)_{4} \mathrm{Cl}_{2}\right] \mathrm{Cl} \cdot \mathrm{H}_{2} \mathrm{O}$ were prepared using catalytic reaction with hydrazinium chloride ([11], see procedure 2.5 above). A total of $0.64 \mathrm{~g} \mathrm{NH}_{4} \mathrm{Cl}$ powder was added to $0.21 \mathrm{~g}\left(\mathrm{NH}_{4}\right)_{3}\left[\mathrm{RhCl}_{6}\right] \cdot \mathrm{H}_{2} \mathrm{O}$ and dissolved in $10 \mathrm{~mL}$ water; mixture was boiled until a complete dissolution of the precipitate. Further addition of $0.27-\mathrm{g}$ solid $\mathrm{CH}_{3} \mathrm{COONH}_{4}$ and a few milligrams of $\mathrm{N}_{2} \mathrm{H}_{6} \mathrm{Cl}_{2}$ powder, resulted in an immediate color change from red to golden-yellow. Additional portions of $\mathrm{CH}_{3} \mathrm{COONH}_{4}$ were added (max $0.1 \mathrm{~g}$ ) to the reaction mixture to keep $\mathrm{pH} 7$. After cooling to room temperature, a golden-yellow precipitate was filtered. Single crystals were collected from the stock solution, after its evaporation. A total of 1-mm light-yellow needles were collected from the surface of the solution, after completion of the reaction and cooling to room temperature (room temperature $\mathrm{X}$-ray diffraction experiment). An additional portion of the crystals 
was obtained after evaporation of the solution after two weeks (crystals were used for low temperature X-ray diffraction experiment).

Light-orange, plate-shaped single crystals of cis-[ $\left.\mathrm{Rh}\left(\mathrm{NH}_{3}\right)_{4} \mathrm{Cl}_{2}\right] \mathrm{Cl}$ were prepared using an autoclave reaction of $\left[\mathrm{Rh}\left(\mathrm{NH}_{3}\right)_{5} \mathrm{Cl}\right] \mathrm{Cl}_{2}$ with $\mathrm{Na}_{2} \mathrm{C}_{2} \mathrm{O}_{4}$ and $\mathrm{H}_{2} \mathrm{C}_{2} \mathrm{O}_{4}$, without isolation of the $\left[\mathrm{Rh}\left(\mathrm{NH}_{3}\right)_{4}\left(\mathrm{C}_{2} \mathrm{O}_{4}\right)\right] \mathrm{ClO}_{4} \cdot \mathrm{H}_{2} \mathrm{O}$ intermediate ([13], see procedure 2.6 above). A mixture of $50 \mathrm{mg}$ $\left[\mathrm{Rh}\left(\mathrm{NH}_{3}\right)_{5} \mathrm{Cl}\right] \mathrm{Cl}_{2}, 23 \mathrm{mg} \mathrm{Na} \mathrm{C}_{2} \mathrm{O}_{4}$, and $13 \mathrm{mg} \mathrm{H}_{2} \mathrm{C}_{2} \mathrm{O}_{4}$ was dissolved in $5 \mathrm{~mL}$ of water, placed in a stainless steel autoclave and heated at $120{ }^{\circ} \mathrm{C}$, for $48 \mathrm{~h}$. After finishing the first step, the reaction mixture was heated with $1 \mathrm{~mL}$ of concentrated $\mathrm{HCl}$ water solution. After cooling to room temperature, the light-yellow precipitate (unreacted $\left.\left[\mathrm{Rh}\left(\mathrm{NH}_{3}\right)_{5} \mathrm{Cl}\right] \mathrm{Cl}_{2}\right)$ was filtered. Light-orange stock solution was evaporated for several days in air, at room temperature. Orange crystals of cis- $\left[\mathrm{Rh}\left(\mathrm{NH}_{3}\right)_{4} \mathrm{Cl}_{2}\right] \mathrm{Cl}$ were contaminated with minimum light-yellow $\left[\mathrm{Rh}\left(\mathrm{NH}_{3}\right)_{5} \mathrm{Cl}\right] \mathrm{Cl}_{2}$ crystals, as well as with large light-yellow needles of an unknown crystal structure and composition.

$\left[\mathrm{Rh}\left(\mathrm{NH}_{3}\right)_{5} \mathrm{Cl}\right] \mathrm{Cl}_{2}$ was prepared using a catalytic procedure with hydrazinium chloride $([7,23]$, see procedure 2.7 above). A total of $1 \mathrm{~g}$ of $\mathrm{RhCl}_{3} \cdot x \mathrm{H}_{2} \mathrm{O}$ powder was dissolved in $10 \mathrm{~mL}$ of concentrated $\mathrm{HCl}$ and heated for $0.5 \mathrm{~h}$. After a complete dissolution, a few milligrams of solid $\mathrm{N}_{2} \mathrm{H}_{6} \mathrm{Cl}_{2}$ was added together with $20 \mathrm{~mL}$ of hot ammonia buffer, with $\mathrm{pH}$ 8.2. Immediately, the solution turned to light-yellow, with a formation of $\left[\mathrm{Rh}\left(\mathrm{NH}_{3}\right)_{5} \mathrm{Cl}\right] \mathrm{Cl}_{2}$ precipitate. The precipitate was filtered and washed from $\left[\mathrm{Rh}\left(\mathrm{NH}_{3}\right)_{4} \mathrm{Cl}_{2}\right] \mathrm{Cl}$, with hot $\mathrm{HCl}$ water solution (2:1). A total of $10 \mathrm{mg}$ of $\left[\mathrm{Rh}\left(\mathrm{NH}_{3}\right)_{5} \mathrm{Cl}\right] \mathrm{Cl}_{2}$ powder was dissolved in hot water and evaporated at room temperature to get $\left[\mathrm{Rh}\left(\mathrm{NH}_{3}\right)_{5} \mathrm{Cl}_{1} \mathrm{Cl}_{2}\right.$ single crystals.

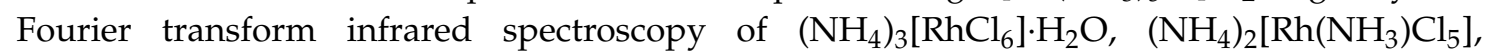
and trans- $\left[\mathrm{Rh}\left(\mathrm{NH}_{3}\right)_{4} \mathrm{Cl}_{2}\right] \mathrm{Cl} \cdot \mathrm{H}_{2} \mathrm{O}$ (FTIR, Digi-lab Excalibur FTS 3000 FTIR) was recorded in transmission in the range of 4000-500 $\mathrm{cm}^{-1}$, using the ART optic (MK11 Golden Gate system). Raman spectra were collected on a Raman ART optic spectrometer MK11 Golden Gate system.

The single crystal X-ray diffraction (SC-XRD) study of trans-[Rh( $\left.\left(\mathrm{NH}_{3}\right)_{4} \mathrm{Cl}_{2}\right] \mathrm{Cl}_{2} \cdot \mathrm{H}_{2} \mathrm{O}$ and $\left[\mathrm{Rh}\left(\mathrm{NH}_{3}\right)_{5} \mathrm{Cl}\right] \mathrm{Cl}_{2}$ single crystals was performed on an automated Bruker APEX-II CCD diffractometer (MoK $\alpha$ radiation, graphite monochromator, and two-dimensional CCD detector) at $150 \mathrm{~K}$ at the BAM. The structure was refined in the anisotropic approximation. Hydrogen atoms were set geometrically. All calculations were performed using the SHELXTL software [26]. For the refinement of trans- $\left[\mathrm{Rh}\left(\mathrm{NH}_{3}\right)_{4} \mathrm{Cl}_{2}\right] \mathrm{Cl} \cdot \mathrm{H}_{2} \mathrm{O}$ at $150 \mathrm{~K}$, in the final full-matrix refinement of 88 structural parameters, the total number of reflexes used was 3813 and the divergence factors were: $R_{\text {all }}=2.78 \%, w R_{\text {ref }}=8.49 \%$; for 3747 reflections with $I \geq 2 \sigma(I), R_{\mathrm{gt}}=2.75 \%, w R_{\mathrm{gt}}=8.48 \%, S$ factor against $F^{2}$ was 1.179 . For the refinement of cis- $\left[\mathrm{Rh}\left(\mathrm{NH}_{3}\right)_{4} \mathrm{Cl}_{2}\right] \mathrm{Cl}$ at $150 \mathrm{~K}$, in the final full-matrix refinement of 43 structural parameters, the total number of reflexes used was 1186 and the divergence factors were: $R_{\text {all }}=4.19 \%$, $w R_{\text {ref }}=12.27 \%$; for 1185 reflections with $I \geq 2 \sigma(I), R_{\mathrm{gt}}=4.19 \%$, $w R_{\mathrm{gt}}=12.27 \%$, $S$ factor against $F^{2}$ was 1.359. For the refinement of $\left[\mathrm{Rh}\left(\mathrm{NH}_{3}\right)_{5} \mathrm{Cl}\right] \mathrm{Cl}_{2}$ at $150 \mathrm{~K}$, in the final full-matrix refinement of 49 structural parameters, the total number of reflexes used was 2347 and the divergence factors were: $R_{\text {all }}=5.99 \%, w R_{\text {ref }}=13.35 \%$; for 2099 reflections with $I \geq 2 \sigma(I), R_{\mathrm{gt}}=5.11 \%, w R_{\mathrm{gt}}=12.85 \%, S$ factor against $F^{2}$ was 1.085 .

The X-ray diffraction study of trans-[Rh( $\left.\left(\mathrm{NH}_{3}\right)_{4} \mathrm{Cl}_{2}\right] \mathrm{Cl} \cdot \mathrm{H}_{2} \mathrm{O}$ and $\left(\mathrm{NH}_{4}\right)_{2}\left[\mathrm{Rh}\left(\mathrm{NH}_{3}\right) \mathrm{Cl}_{5}\right]$ single crystals was performed on an automated Bruker APEX-II CCD diffractometer (MoK $\alpha$ radiation, graphite monochromator, and two-dimensional CCD detector), at room temperature, at the Nikolaev Institute. For the refinement of trans- $\left[\mathrm{Rh}\left(\mathrm{NH}_{3}\right)_{4} \mathrm{Cl}_{2}\right] \mathrm{Cl} \cdot \mathrm{H}_{2} \mathrm{O}$ at room temperature, in the final full-matrix refinement of 94 structural parameters, the total number of reflexes used was 3928 and the divergence factors were: $R_{\mathrm{all}}=4.64 \%, w R_{\mathrm{ref}}=10.56 \%$; for 3308 reflections with $I \geq 2 \sigma(I), R_{\mathrm{gt}}=3.79 \%, w R_{\mathrm{gt}}=10.04 \%$, $S$ factor against $F^{2}$ was 1.038 . For the refinement of $\left(\mathrm{NH}_{4}\right)_{2}\left[\mathrm{Rh}\left(\mathrm{NH}_{3}\right) \mathrm{Cl}_{5}\right]$ at room temperature, in the final full-matrix refinement of 66 structural parameters, the total number of reflexes used was 1886 and the divergence factors were: $R_{\text {all }}=1.93 \%, w R_{\text {ref }}=4.29 \%$; for 1748 reflections with $I \geq 2 \sigma(I), R_{\mathrm{gt}}=1.71 \%$, $w R_{\mathrm{gt}}=4.20 \%$, $S$ factor against $F^{2}$ was 1.078 . 


\section{Crystal Structures of Rh(III) Chloroamines}

Crystallographic characteristics of $\mathrm{Rh}(\mathrm{III})$ chloroamines are summarized in Table 1.

Table 1. Crystallographic data for $\left[\mathrm{RhCl}_{x}\left(\mathrm{NH}_{3}\right)_{6-x}\right]$ complexes.

\begin{tabular}{|c|c|c|c|c|c|c|c|c|c|c|c|}
\hline Composition & $\begin{array}{c}\left(\mathrm{NH}_{4}\right)_{3}\left[\mathrm{RhCl}_{6}\right] \cdot \mathrm{H}_{2} \mathrm{O}^{\mathrm{a}} \\
\text { SC-XRD, RT }\end{array}$ & $\begin{array}{c}\left(\mathrm{NH}_{4}\right)_{2}\left[\mathrm{Rh}\left(\mathrm{NH}_{3}\right) \mathrm{Cl}_{5}\right] \\
\text { SC-XRD, RT }\end{array}$ & $\begin{array}{l}\mathrm{K}_{2}\left[\mathrm{Rh}\left(\mathrm{NH}_{3}\right) \mathrm{Cl}_{5}\right] \\
\mathrm{SC}-\mathrm{XRD}, \mathrm{RT}\end{array}$ & $\begin{array}{c}c i s-\mathrm{K}\left[\mathrm{Rh}_{(}\left(\mathrm{NH}_{3}\right)_{2} \mathrm{Cl}_{4}\right] \cdot \mathrm{KCl} \\
\mathrm{SC}-\mathrm{XRD}, \mathrm{RT}\end{array}$ & $\begin{array}{c}\left.f a c-\left[\mathrm{Rh}_{(} \mathrm{NH}_{3}\right)_{3} \mathrm{Cl}_{3}\right] \\
\text { PXRD, RT }\end{array}$ & $\begin{array}{c}\text { trans- }\left[\mathrm{Rh}\left(\mathrm{NH}_{3}\right)_{4} \mathrm{Cl}_{2}\right] \mathrm{Cl} \\
\mathrm{SC}-\mathrm{XRD}, \mathrm{RT}\end{array}$ & $\begin{array}{c}\text { trans- }\left[\mathrm{Rh}\left(\mathrm{NH}_{3}\right)_{4} \mathrm{Cl}_{2}\right] \mathrm{Cl} \cdot \mathrm{H}_{2} \mathrm{O} \\
\mathrm{SC}-\mathrm{XRD}, \mathrm{RT}\end{array}$ & $\begin{array}{c}\text { trans- }\left[\mathrm{Rh}\left(\mathrm{NH}_{3}\right)_{4} \mathrm{Cl}_{2}\right] \mathrm{Cl} \cdot \mathrm{H}_{2} \mathrm{O} \\
\mathrm{SC}-\mathrm{XRD}, 150 \mathrm{~K}\end{array}$ & $\begin{array}{c}c i s-\left[\mathrm{Rh}_{(}\left(\mathrm{NH}_{3}\right)_{4} \mathrm{Cl}_{2}\right] \mathrm{Cl} \\
\mathrm{SC}-\mathrm{XRD}, 150 \mathrm{~K}\end{array}$ & $\begin{array}{l}{\left[\mathrm{Rh}\left(\mathrm{NH}_{3}\right)_{5} \mathrm{CllCl}_{2}\right.} \\
\mathrm{SC}-\mathrm{XRD}, 150 \mathrm{~K}\end{array}$ & $\begin{array}{l}{\left[\mathrm{Rh}\left(\mathrm{NH}_{3}\right)_{6}\right] \mathrm{Cl}_{3}} \\
\text { SC-XRD, } 150 \mathrm{~K}\end{array}$ \\
\hline [Ref.] & {$[16,17]$} & [current study] & {$[8]$} & {$[8]$} & {$[6]$} & [27] & [current study] & [current study] & [current study] & [current study] $^{\mathrm{b}}$ & [6] \\
\hline Colour & ruby-red & orange-red & dark-red & red & light-yellow & pale-yellow & pale-yellow & light-orange & yellow & light-yellow & colourless \\
\hline Space group & Рита (62) & Рита (62) & Рита (62) & $C 2 / m(12)$ & $P 21 / m(11)$ & $P \overline{1}(2)$ & $P \overline{1}(2)$ & $\mathrm{P} \overline{1}(2)$ & $\operatorname{R3m}(160)$ & Рпта (62) & $C 2 / m(12)$ \\
\hline$a, \AA$ & $12.213(3) ; 12.193(4)$ & $13.3982(3)$ & $13.464(6)$ & $11.822(5)$ & $6.72793(26)$ & $6.35(2)$ & $5.8697(7)$ & $5.83411(6)$ & $19.600(4)$ & $13.2770(13)$ & $12.6244(10)$ \\
\hline$b, \AA$ & $7.012(1) ; 7.007(4)$ & $10.2926(2)$ & $9.989(4)$ & $11.608(5)$ & $9.78879(38)$ & $5.77(2)$ & $6.4606(7)$ & $6.4469(7)$ & $19.600(4)$ & $10.4930(9)$ & $21.499(2)$ \\
\hline$c, \AA$ & $14.151(3) ; 14.167(10)$ & $6.8177(2)$ & $6.932(3)$ & $8.196(4)$ & $5.46106(20)$ & $13.81(5)$ & $12.5870(13)$ & $12.5189(12)$ & $6.3357(13)$ & $6.6578(6)$ & $12.9439(16)$ \\
\hline 10 & 90 & (2) & 90 & 90 & 90 & $115.3(2)$ & $85.412(5)$ & $94.430(4)$ & 90 & 90 & 90 \\
\hline$\beta,{ }^{\circ}$ & 90 & 90 & 90 & 107.56(2) & 90 & $99.6(2)$ & $89.721(6)$ & $90.029(4)$ & 90 & 90 & 113.188 \\
\hline$\gamma,{ }^{\circ}$ & 90 & 90 & 90 & 90 & 90 & $77.5(2)$ & $77.767(5)$ & $102.407(4)$ & 120 & 90 & 90 \\
\hline$z$ & 4 & 4 & 4 & 4 & 2 & 2 & 2 & 2 & 9 & 4 & 12 \\
\hline$V, \AA^{3}$ & 1211.9(5); 1210.38(2) & $940.18(4)$ & $932.23(7)$ & $1072.42(8)$ & 358.2 & $445.0(5)$ & $464.95(9)$ & $458.42(8)$ & 2107.9(9) & 927.54(15) & 3229.33 \\
\hline ICSD & 61129; 202826 & 1965928 & 430397 & 430395 & 426435 & - & 1965934 & 1965942 & 1965940 & 1965941 & 187073 \\
\hline$h_{1} k_{1} l_{1}$ & 011 & 011 & $0-11$ & -111 & 110 & $00-2$ & 010 & 010 & 202 & 011 & $-1-31$ \\
\hline$h_{2} k_{2} l_{2}$ & $-1-20$ & $01-1$ & $0-1-1$ & $-1-11$ & $1-10$ & 100 & 101 & 101 & 022 & $01-1$ & -131 \\
\hline$h_{3} k_{3} l_{3}$ & 200 & $-2-10$ & 210 & -210 & 001 & 010 & -101 & -101 & 003 & $-2-10$ & $00-2$ \\
\hline$a_{\mathrm{T}}$ & $-a$ & $-a / 4+b / 2+c / 2$ & $a / 4-b / 2-c / 2$ & $b / 2+c / 2$ & $a / 2+b / 2$ & $c / 2$ & $b$ & $b$ & $a / 2$ & $-a / 4+b / 2+c / 2$ & $-a / 2-b / 6$ \\
\hline$b_{\mathrm{T}}$ & $-b / 2-c / 2$ & $-a / 4+b / 2-c / 2$ & $a / 4-b / 2+c / 2$ & $-b / 2+c / 2$ & $a / 2+b / 2$ & $a$ & $a / 2+c / 2$ & $a / 2+c / 2$ & $b / 2$ & $a / 4-b / 2+c / 2$ & $-a / 2+b / 6$ \\
\hline$c_{\mathrm{T}_{\mathrm{o}}}$ & $a / 2-b / 4-c / 4$ & $-a / 2$ & $a / 2$ & $-a / 2-c / 2$ & $c$ & $b$ & $-a / 2+c / 2$ & $-a / 2+c / 2$ & $a / 3+b / 3-c / 3$ & $-a / 2$ & $-a / 2-c / 2$ \\
\hline$a_{\mathrm{T}}, \AA$ & 7.01 & 7.02 & 6.95 & 7.11 & 5.94 & 6.91 & 6.46 & 6.44 & 9.80 & 7.04 & 7.26 \\
\hline$b_{\mathrm{T}}, \AA$ & 7.90 & 7.02 & 6.95 & 7.11 & 5.94 & 6.35 & 6.96 & 6.90 & 9.80 & 7.04 & 7.26 \\
\hline$c_{\mathrm{T}} \cdot \AA$ & 7.27 & 6.70 & 6.73 & 6.09 & 5.46 & 5.77 & 6.93 & 6.90 & 6.87 & 6.64 & 7.04 \\
\hline$\overline{a_{T}, b_{T} C_{T^{\prime}}} \AA$ & 7.39 & 6.91 & 6.88 & 6.77 & 5.78 & 6.34 & 6.78 & 6.75 & & 6.91 & 7.19 \\
\hline$\alpha_{\mathrm{T}},{ }^{\circ}$ & 57,1 & 61.5 & 61.03 & 102.7 & 92.9 & 77.5 & 50.0 & 49.9 & 61.6 & 61.9 & 59.2 \\
\hline $\begin{array}{l}\beta_{\mathrm{T}},{ }^{0} \\
\gamma_{\mathrm{T}}\end{array}$ & $\begin{array}{l}76,1 \\
636\end{array}$ & $\begin{array}{l}61.5 \\
581\end{array}$ & $\begin{array}{l}61.03 \\
59.84\end{array}$ & $\begin{array}{l}102.7 \\
1096\end{array}$ & $\begin{array}{l}92.9 \\
1110\end{array}$ & $\begin{array}{l}64.7 \\
804\end{array}$ & $\begin{array}{l}91.0 \\
807\end{array}$ & $\begin{array}{l}91.1 \\
80.8\end{array}$ & 61.6 & 61.9 & $\begin{array}{l}62.3 \\
592 \\
597\end{array}$ \\
\hline$\frac{\gamma_{\mathrm{T}},{ }^{\circ}}{\alpha_{T}, \beta \gamma_{T}}, \circ$ & $\begin{array}{l}63,6 \\
65.6\end{array}$ & $\begin{array}{l}58.1 \\
60.4\end{array}$ & 59.84 & $\begin{array}{l}109.6 \\
105.0\end{array}$ & $\begin{array}{l}1111.0 \\
98.9\end{array}$ & $\begin{array}{l}80.4 \\
74.2\end{array}$ & $\begin{array}{l}80.7 \\
73.9\end{array}$ & $\begin{array}{l}80.8 \\
73.9\end{array}$ & 120 & 56.4 & 59.2 \\
\hline$\alpha_{T,}, \beta_{T} \gamma_{T^{\prime}}{ }^{\circ}$ & 65.6 & 60.4 & 60.6 & 105.0 & 98.9 & 74.2 & 73.9 & 73.9 & & 60.1 & 60.2 \\
\hline
\end{tabular}

Bold correspond to vectoctor, all letters in the line represent corresponding translational vectors. a) no experimental data for $\left(\mathrm{NH}_{4}\right)_{3}\left[\mathrm{RhCl}_{6}\right]$, it is probably isostructural to $\left(\mathrm{NH}_{4}\right)_{3}\left[\mathrm{IrCl}_{6}\right]$ [28]:

$P \overline{1}(2), a=12.602(30), b=7.226(20), c=7.502(20) \AA, \alpha=119.18(59), \beta=91.60(50)^{\circ}, \gamma=106.70(50)^{\circ}$. For $\left(\mathrm{NH}_{4}\right)_{3}\left[\operatorname{IrCl}_{6}\right], a_{\mathrm{T}}=(-200)=-a / 2-c / 2=7.24, b_{\mathrm{T}}=(010)=b=7.23, c_{\mathrm{T}}=(10-1)=$

$-c=7.50 \AA, \alpha_{\mathrm{T}}=60.8, \beta_{\mathrm{T}}=60.4, \gamma_{\mathrm{T}}=59.8^{\circ}$; b) previous data for $\left[\mathrm{Rh}\left(\mathrm{NH}_{3}\right)_{5} \mathrm{Cl}_{\mathrm{Cl}} \mathrm{Cl}_{2}(\mathrm{SC}-\mathrm{XRD}, \mathrm{RT}[29,30]):\right.$ Pnma $(62), a=13.36(1), b=10.46(1), c=6.741(8) \AA, V=942.0 \AA^{3}, \mathrm{ICSD} 1524334$. 
Coordination of $\mathrm{Rh}(\mathrm{III})$ in all crystal structures are shown in Figure 1. Crystal structures of all coordination compounds mentioned above are summarized in Figure 2. Almost all salts had a relatively low crystal symmetry and crystallized in triclinic, monoclinic, and especially in orthorhombic (Pnma) space groups. Only cis-[ $\left.\mathrm{Rh}\left(\mathrm{NH}_{3}\right)_{4} \mathrm{Cl}_{2}\right] \mathrm{Cl}$ crystallized in the $\mathrm{R} 3 m$ space group. It should be noted that in all cases the highest symmetry of $\mathrm{Rh}(\mathrm{IIII})$ octahedron is $m$, even in potentially symmetric fac- $\left[\mathrm{Rh}\left(\mathrm{NH}_{3}\right)_{3} \mathrm{Cl}_{3}\right],\left[\mathrm{RhCl}_{6}\right]^{3-}$, and $\left[\mathrm{Rh}\left(\mathrm{NH}_{3}\right)_{6}\right]^{3+}$. Nevertheless, in all described complexes, $\mathrm{Rh}(\mathrm{III})$ had a nearly ideal octahedral coordination. Deviations of valence angles from $90^{\circ}$ between $\mathrm{Cl}$ and $\mathrm{NH}_{3}$ ligands were relatively small and usually below $5^{\circ}$. All crystals structures had relatively dense packing, without formation of any channels or cages. As a result, almost all complexes crystallized without crystal water. Only $\left(\mathrm{NH}_{4}\right)_{3}\left[\mathrm{RhCl}_{6}\right] \cdot \mathrm{H}_{2} \mathrm{O}$ had crystal water in its structure. In all existing examples, such as $\left(\mathrm{NH}_{4}\right)_{2}\left[\mathrm{Rh}\left(\mathrm{NH}_{3}\right) \mathrm{Cl}_{5}\right]$ and $\mathrm{K}_{2}\left[\mathrm{Rh}\left(\mathrm{NH}_{3}\right) \mathrm{Cl}_{5}\right]$ as well as $\left(\mathrm{NH}_{4}\right)_{3}\left[\mathrm{RhCl}_{6}\right] \cdot \mathrm{H}_{2} \mathrm{O}$ and $\mathrm{K}_{3}\left[\mathrm{RhCl}_{6}\right] \cdot \mathrm{H}_{2} \mathrm{O}$, ammonium and potassium salts seemed to be isomorphous to each other, but the sodium salts usually showed different crystal structures $[15,28]$. It should be noted that previously reported water-free trans $-\left[\mathrm{Rh}\left(\mathrm{NH}_{3}\right)_{4} \mathrm{Cl}_{2}\right] \mathrm{Cl}$, according to [21] and the current study seemed to have crystal water and should be written as trans- $\left[\mathrm{Rh}\left(\mathrm{NH}_{3}\right)_{4} \mathrm{Cl}_{2}\right] \mathrm{Cl} \cdot \mathrm{H}_{2} \mathrm{O}$.

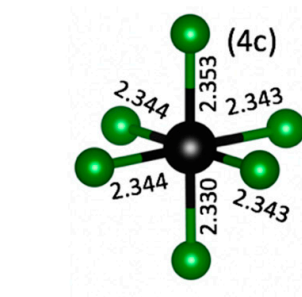

$\left[\mathrm{RhCl}_{6}\right]^{3-}$ in $\left(\mathrm{NH}_{4}\right)_{3}\left[\mathrm{RhCl}_{6}\right] \cdot \mathrm{H}_{2} \mathrm{O}[16]$

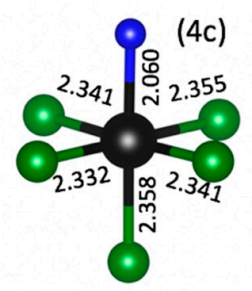

$\left[\mathrm{Rh}\left(\mathrm{NH}_{3}\right) \mathrm{Cl}_{5}\right]^{2-}$ in $\left(\mathrm{NH}_{4}\right)_{2}\left[\mathrm{Rh}\left(\mathrm{NH}_{3}\right) \mathrm{Cl} \mathrm{C}_{5}\right]$

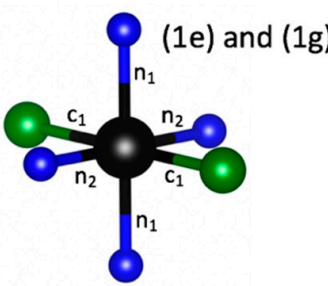

$$
\text { cis- }\left[\mathrm{Rh}\left(\mathrm{NH}_{3}\right)_{4} \mathrm{Cl}_{2}\right]^{+}
$$
in cis- $\left[\mathrm{Rh}\left(\mathrm{NH}_{3}\right)_{4} \mathrm{Cl}_{2}\right] \mathrm{Cl}$ in trans-[Rh( $\left.\left(\mathrm{NH}_{3}\right)_{4} \mathrm{Cl} \mathrm{Cl}_{2}\right] \mathrm{Cl} \cdot \mathrm{H}_{2} \mathrm{O}$

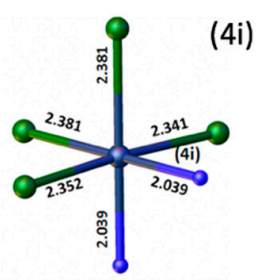

cis-[Rh( $\left.\left(\mathrm{NH}_{3}\right)_{2} \mathrm{Cl}_{4}\right]^{-}$ in cis- $\mathrm{K}\left[\mathrm{Rh}\left(\mathrm{NH}_{3}\right)_{2} \mathrm{Cl}{ }_{4}\right] \cdot \mathrm{KCl}[8]$

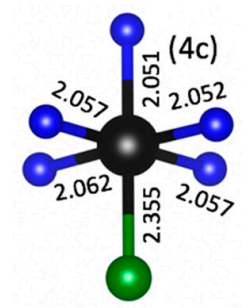

$\left[\mathrm{Rh}\left(\mathrm{NH}_{3}\right)_{5} \mathrm{Cl}\right]^{2+}$ in $\left[\mathrm{Rh}\left(\mathrm{NH}_{3}\right)_{5} \mathrm{Cl}\right] \mathrm{Cl}{ }_{2}$

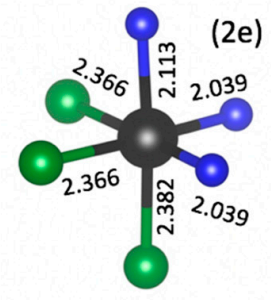

fac- $\left[\mathrm{Rh}\left(\mathrm{NH}_{3}\right)_{3} \mathrm{Cl}_{3}\right][6]$

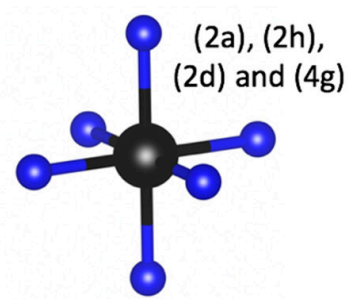

$\left[\mathrm{Rh}\left(\mathrm{NH}_{3}\right)_{6}\right]^{3+}$ in $\left[\mathrm{Rh}\left(\mathrm{NH}_{3}\right)_{6}\right] \mathrm{Cl}_{3}[7]$

Figure 1. Coordination polyhedrons of $\mathrm{Rh}(\mathrm{III})$ (black) and their point symmetry in $\left[\mathrm{RhCl}_{x}\left(\mathrm{NH}_{3}\right)_{6-x}\right]$ crystal structures with ammonium or chloride as counter ions (see Table 1 for crystallographic details). Green balls represent Cl-ligand, blue- $\mathrm{NH}_{3}$. For trans- $\left[\mathrm{Rh}\left(\mathrm{NH}_{3}\right)_{4} \mathrm{Cl}_{2}\right] \mathrm{Cl} \cdot \mathrm{H}_{2} \mathrm{O}, \mathrm{n}_{1}=2.062(1 \mathrm{e})$ and 2.055 (1g), $\mathrm{n}_{2}=2.060(1 \mathrm{e})$ and $2.053(1 \mathrm{~g}), \mathrm{c}_{1}=2.332(1 \mathrm{e})$ and $2.328(1 \mathrm{~g}) \AA$; interatomic distances for four crystallographically independent $\mathrm{RhN}_{6}$ cations, in crystal structures of $\left[\mathrm{Rh}\left(\mathrm{NH}_{3}\right)_{6}\right] \mathrm{Cl}_{3}$ are given in the text.

In the crystal structure of $\left(\mathrm{NH}_{4}\right)_{3}\left[\mathrm{RhCl}_{6}\right] \cdot \mathrm{H}_{2} \mathrm{O},\left[\mathrm{RhCl}_{6}\right]^{3-}$ anions occupy special positions corresponding to mirror planes, where $\mathrm{Rh}$ and two $\mathrm{Cl}$ ligands sit on the plane. The crystal structure is quite regular with only $\mathrm{N} \ldots \mathrm{Cl}$ short contacts of about 3.21-3.28 $\AA$.

Crystal structures of $\left(\mathrm{NH}_{4}\right)_{2}\left[\mathrm{Rh}\left(\mathrm{NH}_{3}\right) \mathrm{Cl}_{5}\right]$ and $\mathrm{K}_{2}\left[\mathrm{Rh}\left(\mathrm{NH}_{3}\right) \mathrm{Cl}_{5}\right]$ [8] are very similar and belong to a large series of isostructural isoformular $\mathrm{A}_{2}\left[\mathrm{ML}_{5} \mathrm{X}\right]$ complexes. In their crystal structures, $\left[\mathrm{Rh}\left(\mathrm{NH}_{3}\right) \mathrm{Cl}_{5}\right]^{2-}$ cations lie on the mirror plane. $\mathrm{Rh} \mathrm{NH}_{3}$, trans- $\mathrm{Cl}$, and two cis- $\mathrm{Cl}$ ligands occupy positions in the mirror plane; two cis- $\mathrm{Cl}$ ligands are symmetrically connected by the plane. Rh...Rh distances are 6.364-7.274 $\AA$. Isostructural similarity of $\left(\mathrm{NH}_{4}\right)_{2}\left[\mathrm{Rh}\left(\mathrm{NH}_{3}\right) \mathrm{Cl} 5\right]$ and $\left[\mathrm{Rh}\left(\mathrm{NH}_{3}\right)_{5} \mathrm{Cl}\right] \mathrm{Cl}_{2}$ salts is the main important structural feature within the series. If in $\left[\mathrm{Rh}\left(\mathrm{NH}_{3}\right)_{5} \mathrm{Cl}\right] \mathrm{Cl}_{2}$ all $\mathrm{Cl}$ positions were filled with 
nitrogen ligands and all nitrogen positions were filled with $\mathrm{Cl}$ atoms, nearly ideal crystals structures of $\left(\mathrm{NH}_{4}\right)_{2}\left[\mathrm{Rh}\left(\mathrm{NH}_{3}\right) \mathrm{Cl}_{5}\right]$ can be obtained. Both crystal structures had similar cell parameters. Such a phenomenon has been also found for isomorphous $\left(\mathrm{NH}_{4}\right)_{2}\left[\operatorname{Ir}\left(\mathrm{NH}_{3}\right) \mathrm{Cl}_{5}\right]$ and $\left[\operatorname{Ir}\left(\mathrm{NH}_{3}\right)_{5} \mathrm{Cl}_{\mathrm{Cl}} \mathrm{Cl}_{2}\right.$ salts, as well as $\left(\mathrm{NH}_{4}\right)_{2}\left[\mathrm{~V}\left(\mathrm{NH}_{3}\right) \mathrm{Cl}_{5}\right]$ and $\left[\mathrm{Rh}\left(\mathrm{NH}_{3}\right)_{5} \mathrm{Cl}\right] \mathrm{Cl}_{2}$ complexes [29,31]. In both types of crystal structures, the Rh(III) octahedra occupy positions on the mirror plane. Both structures have deformed $\mathrm{CaF}_{2}$ fluorite structure types, where coordination ions occupy Ca positions and contra-ions correspond to the $\mathrm{F}$ positions. $\left(\mathrm{NH}_{4}\right)_{2}\left[\mathrm{Rh}\left(\mathrm{NH}_{3}\right) \mathrm{Cl}_{5}\right]$ and $\left[\mathrm{Rh}\left(\mathrm{NH}_{3}\right)_{5} \mathrm{Cl}\right] \mathrm{Cl}_{2}$ can be considered as anti-isomorphic pairs of crystal structures. As soon as both $\left(\mathrm{NH}_{4}\right)_{2}\left[\mathrm{Rh}\left(\mathrm{NH}_{3}\right) \mathrm{Cl}_{5}\right]$ and $\left[\mathrm{Rh}\left(\mathrm{NH}_{3}\right)_{5} \mathrm{Cl}\right] \mathrm{Cl}_{2}$ have similar crystal structures, it would be interesting to prepare their co-salts to check a possibility to get isomorphous double salts, without miscibility such as $\left(\mathrm{NH}_{4}\right)_{2-2 x}\left[\mathrm{Rh}\left(\mathrm{NH}_{3}\right) \mathrm{Cl}_{5}\right]_{1-x}\left[\mathrm{Rh}\left(\mathrm{NH}_{3}\right)_{5} \mathrm{Cl}\right]_{x} \mathrm{Cl}_{2+2 x}$, double salts with a fixed composition with $\mathrm{NH}_{4} \mathrm{Cl}$ in its structure, similar to cis- $\mathrm{K}\left[\mathrm{Rh}\left(\mathrm{NH}_{3}\right)_{2} \mathrm{Cl}_{4}\right] \cdot \mathrm{KCl}$, such as $\left[\mathrm{Rh}\left(\mathrm{NH}_{3}\right) \mathrm{Cl}_{5}\right]\left[\mathrm{Rh}\left(\mathrm{NH}_{3}\right)_{5} \mathrm{Cl}\right] \cdot 2 \mathrm{NH}_{4} \mathrm{Cl}$, or double complex salt such as $\left[\mathrm{Rh}\left(\mathrm{NH}_{3}\right) \mathrm{Cl} 5\right]\left[\mathrm{Rh}\left(\mathrm{NH}_{3}\right)_{5} \mathrm{Cl}\right]$, similar to $\left[\mathrm{Rh}\left(\mathrm{NH}_{3}\right) \mathrm{Cl}_{5}\right]\left[\mathrm{IrCl}_{6}\right][32,33]$. It would be also interesting to investigate temperature-induced ligand exchange in such double salts, in the solid-state.
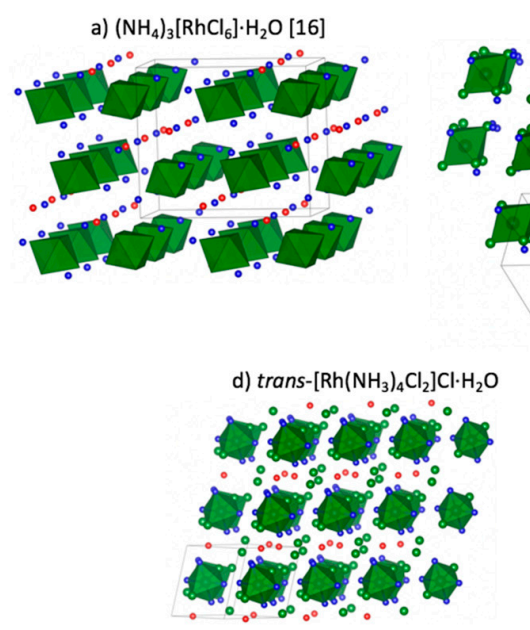

b) $\left(\mathrm{NH}_{4}\right)_{2}\left[\mathrm{Rh}\left(\mathrm{NH}_{3}\right) \mathrm{Cl}_{5}\right]$

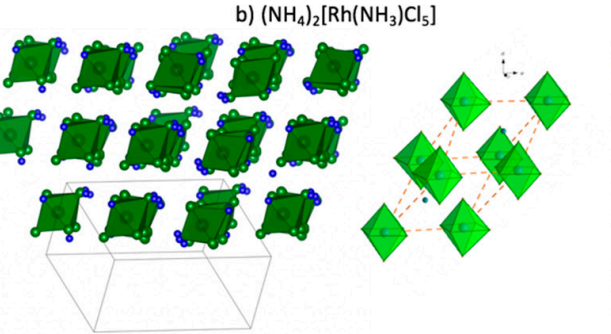

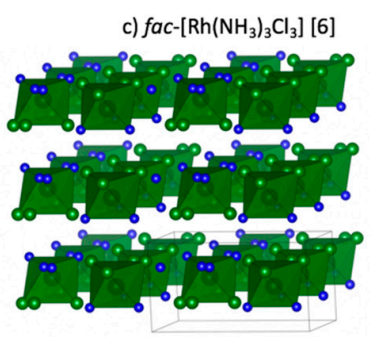

f) $\left[\mathrm{Rh}\left(\mathrm{NH}_{3}\right)_{6}\right] \mathrm{Cl}_{3}[7]$

e) $\left[\mathrm{Rh}\left(\mathrm{NH}_{3}\right)_{5} \mathrm{Cl}\right] \mathrm{Cl}_{2}$
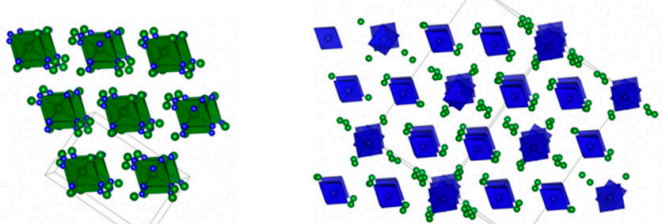

Figure 2. Crystal structures of $\left[\mathrm{RhCl}_{x}\left(\mathrm{NH}_{3}\right)_{6-x}\right]$ species: (a) $\left(\mathrm{NH}_{4}\right)_{3}\left[\mathrm{RhCl}_{6}\right] \cdot \mathrm{H}_{2} \mathrm{O}$ along $b$-direction, two layered hexagonal closed-packed layers are formed perpendicular to the $a$-direction; (b) three layered face-centered closed packing in $\left(\mathrm{NH}_{4}\right)_{2}\left[\mathrm{Rh}\left(\mathrm{NH}_{3}\right) \mathrm{Cl}_{5}\right]$, corresponding pseudo-translational sub-lattice is shown; (c) crystal structure of fac- $\left[\mathrm{Rh}\left(\mathrm{NH}_{3}\right)_{3} \mathrm{Cl}_{3}\right]$ along the $c$-direction, hexagonal layers can be found perpendicular to the $a$-direction; three layered face-centered closed packing in crystal structure of trans- $-\left[\mathrm{Rh}\left(\mathrm{NH}_{3}\right)_{4} \mathrm{Cl}_{2}\right] \mathrm{Cl} \cdot \mathrm{H}_{2} \mathrm{O}(\mathbf{d}),\left[\mathrm{Rh}\left(\mathrm{NH}_{3}\right)_{5} \mathrm{Cl}\right] \mathrm{Cl}_{2}(\mathbf{e})$, and $\left[\mathrm{Rh}\left(\mathrm{NH}_{3}\right)_{6}\right] \mathrm{Cl}_{3}$ (f) $(\mathrm{Rh}$ atoms are shown as black circles, $\mathrm{N}$ atoms are blue, $\mathrm{Cl}$ atoms are green, and $\mathrm{H}$ atoms are omitted for clarity).

Anion cis- $\left[\mathrm{Rh}\left(\mathrm{NH}_{3}\right)_{2} \mathrm{Cl}_{4}\right]^{-}$has been crystallized only as a double salt with $\mathrm{KCl}$, namely cis- $\mathrm{K}\left[\mathrm{Rh}\left(\mathrm{NH}_{3}\right)_{2} \mathrm{Cl}_{4}\right] \cdot \mathrm{KCl}[8]$. The $\mathrm{Rh}$ central atoms occupied a mirror plane as deformed octahedrons $\left[\mathrm{RhN}_{2} \mathrm{Cl}_{4}\right]$. The valence angles divided from $90^{\circ}$ less than $3.7^{\circ}$. The shortest $\mathrm{Rh} . . . \mathrm{Rh}$ distances in the structure were ca. $5.727 \AA . \mathrm{K}^{+}$cations occupied two different positions-inversion center with six $\mathrm{Cl}^{-}$ neighbors and mirror planes with seven $\mathrm{Cl}^{-}$neighbors. The shortest $\mathrm{Rh} . . . \mathrm{K}$ distances were 3.835 and $3.914 \AA$.

Crystal structure of fac- $\left[\mathrm{Rh}\left(\mathrm{NH}_{3}\right)_{3} \mathrm{Cl}_{3}\right]$ has been solved and refined using powder $\mathrm{X}$-ray diffraction data [6]. The monoclinical crystal structure was solved using the direct space approach and was refined using the Rietveld method. In its crystal structure, $\mathrm{Rh}(1), \mathrm{Cl}(1)$, and $\mathrm{N}(1)$ atoms were arranged on a mirror plane. $\mathrm{Rh}-\mathrm{Cl}$ and $\mathrm{Rh}-\mathrm{N}$ bond lengths that lay on the mirror plane, were 0.016 (4) and $0.074(6)$ $\AA$ longer than the others. Deviations of the valence of cis angles on the $\mathrm{Rh}(1)$ atom from the ideal value of $90^{\circ}$ did not exceed $6.8^{\circ}$. Isolated fac- $\left[\mathrm{Rh}\left(\mathrm{NH}_{3}\right)_{3} \mathrm{Cl}_{3}\right]$ octahedrons formed nearly ideal flat hexagonal layers. Layers were oriented perpendicular to the $c$ axis, with the distances between the layers being equal to $c$. All layers followed a simple arrangement without shirts ( $A A$ packing type). 
The crystal structure of trans-[ $\left.\mathrm{Rh}\left(\mathrm{NH}_{3}\right)_{4} \mathrm{Cl}_{2}\right] \mathrm{Cl}$ was obtained based on poor experimental data [21]. Positions of water molecules were not found and refined. So, details of the crystal structure of trans-[ $\left.\mathrm{Rh}\left(\mathrm{NH}_{3}\right)_{4} \mathrm{Cl}_{2}\right] \mathrm{Cl} \cdot \mathrm{H}_{2} \mathrm{O}$ were described here for the first time. The crystal structure contained two independent trans- $\left[\mathrm{Rh}\left(\mathrm{NH}_{3}\right)_{4} \mathrm{Cl}_{2}\right]^{+}$cations; both cations were located in inversion centers. The shortest $\mathrm{Cl}^{-} \ldots \mathrm{N}$ distances were $3.44-3.48 \AA, \mathrm{Cl} \ldots \mathrm{N}$ were $3.28 \AA$, and the crystal water showed O ... N (3.26 and $3.45 \AA)$ and $\mathrm{O}$... Cl (3.38 $\mathrm{A})$ contacts.

Cis- $\left[\mathrm{Rh}\left(\mathrm{NH}_{3}\right)_{4} \mathrm{Cl}_{2}\right] \mathrm{Cl}$ was synthetized in the early 1960 s but its crystal structure was unknown. The crystal structure of the salt had a high symmetry with only one crystallographically independent cis- $\left[\mathrm{Rh}\left(\mathrm{NH}_{3}\right)_{4} \mathrm{Cl}_{2}\right]^{+}$cation located on the mirror plane. Rh and two $\mathrm{N}$ ligands sat on the mirror plane. $\mathrm{Cl}^{-} \ldots . \mathrm{N}$ contacts were 3.32-3.36 $\AA$. The cations formed chains parallel to the $c$-direction with relatively short $\mathrm{Cl}$... N contacts of $3.30 \AA$ (Figure 3). The crystal structure had three-layered packing of cis-[ $\left.\mathrm{Rh}\left(\mathrm{NH}_{3}\right)_{4} \mathrm{Cl}_{2}\right]^{+}$cations with empty space. $\mathrm{Cl}^{-}$anions occupied hexagonal voids.

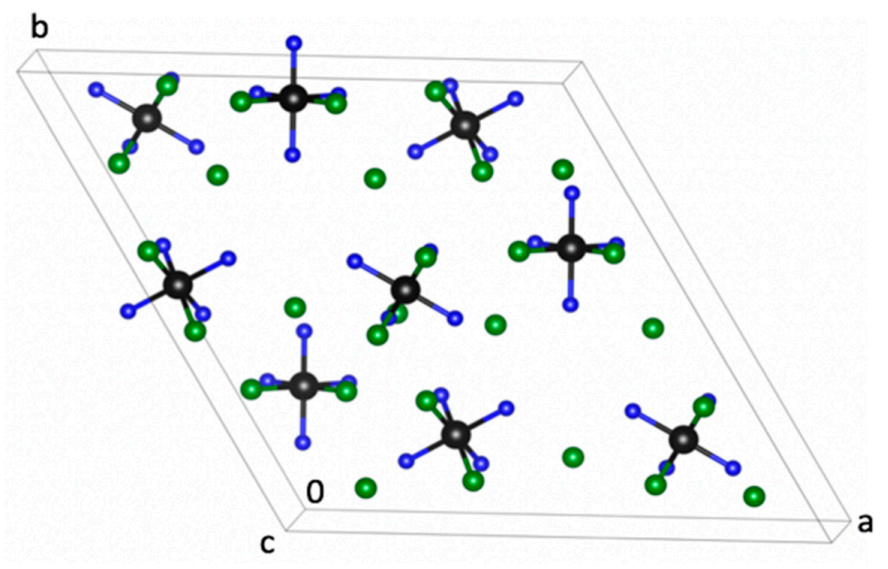

(a)

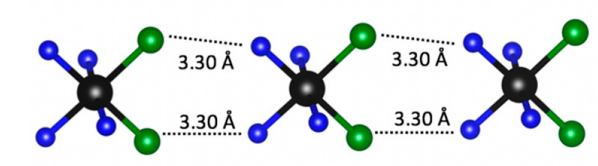

(b)

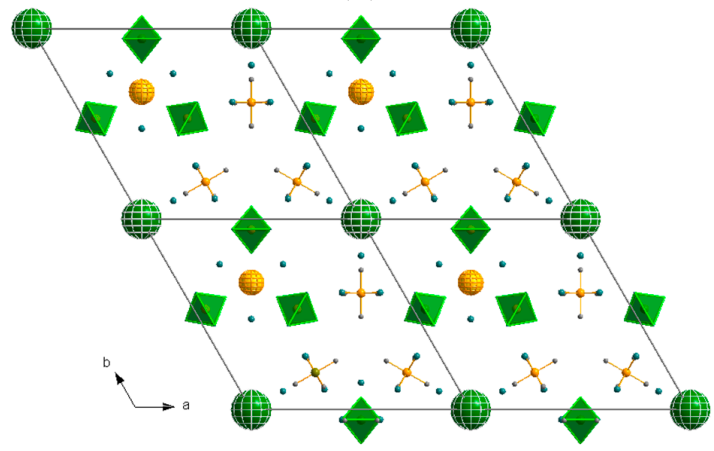

(c)

Figure 3. Crystal structure of $c i s-\left[\mathrm{Rh}\left(\mathrm{NH}_{3}\right)_{4} \mathrm{Cl}_{2}\right] \mathrm{Cl}$ along the $c$-direction (Rh atoms are shown as black circles, nitrogen atoms are blue, chlorine atoms are green, and the hydrogen atoms are omitted for clarity) (a); right: chain along the $c$-direction with the shortest $\mathrm{Cl} \ldots \mathrm{N}$ contacts $(\mathbf{b})$. Three-layered packing in the crystal structure of $c i s-\left[\mathrm{Rh}\left(\mathrm{NH}_{3}\right)_{4} \mathrm{Cl}_{2}\right] \mathrm{Cl}$. First layer of cis- $\left[\mathrm{Rh}\left(\mathrm{NH}_{3}\right)_{4} \mathrm{Cl}_{2}\right]^{+}$is shown as polyhedrons, the second layer is shown in ball-and-stick stile. cis- $\left[\mathrm{Rh}\left(\mathrm{NH}_{3}\right)_{4} \mathrm{Cl}_{2}\right]^{+}$cations have hexagonal arrangement with empty space, which is shown as large balls (the green balls belong to the first layer, yellow balls belong to the second layer, and the small balls represent $\mathrm{Cl}^{-}$anions) (c). 
In the crystal structure of $\left[\mathrm{Rh}\left(\mathrm{NH}_{3}\right)_{6}\right] \mathrm{Cl}_{3}[7]$, there were four non-equal $\left[\mathrm{Rh}\left(\mathrm{NH}_{3}\right)_{6}\right]^{3+}$ cations with Rh-N distances of 2.043-2.072 $\AA$. The N-Rh-N angles were close to $90^{\circ}$. There were close contacts between the coordinated $\mathrm{NH}_{3}$ ligands and the $\mathrm{Cl}^{-}$anions, of about $\mathrm{N} \ldots \mathrm{Cl} 3.27-3.50 \AA$.

All crystal structures had a relatively high packing density and could be described as a closed packing of coordination cations or anions with contra-ions placed in the octahedral or tetrahedral voids of such packings. To find the general orientation of the closed packed layers, a pseudo-translational sublattice could be applied. Pseudo-translation sublattices can be applied to find a minimum sublattice with highest symmetry. Pseudo-translation ordering of structural fragments that can be corresponded to heavy atoms or groups of atoms, such as polyhedral for coordination compounds with the presence of smaller sublattices with higher symmetry, in comparison to the actual symmetry of the unit cell. To find these pseudo-translation sublattices, at least three intersecting crystallographic planes should be found. Crystallographic independent planes should correspond to the heaviest structural fragments, where their concentration is high $[34,35]$. The suitable planes can be found from a powder diffraction pattern as diffraction reflexes with the strongest intensity. Therefore, the general accurate motif of the crystal structure can be described as the most symmetric pseudo-translation sublattice. Briefly, the procedure for selecting a pseudo-translation sublattice should include a choice of the triad of diffraction lines with the strongest diffraction intensity. The diffraction indices of these reflexes should be for a matrix with a determinant $(D)$ equal to the number of heavy fragments in the unit cell $\left(N_{\mathrm{hf}}\right)$. Corresponding intersections between such plains $\left(h_{1} k_{1} l_{1}\right),\left(h_{2} k_{2} l_{2}\right)$, and $\left(h_{3} k_{3} l_{3}\right)$ form a sublattice with a number of heavy fragments equal to $D$. The corresponding vectors $\left(\boldsymbol{a}_{\mathrm{T}}, \boldsymbol{b}_{\mathrm{T}}\right.$ and $\left.\boldsymbol{c}_{\mathrm{T}}\right)$ should give the nearest sites of the initial lattice and angles $\left(\alpha_{\mathrm{T}}, \beta_{\mathrm{T}}\right.$ and $\left.\gamma_{\mathrm{T}}\right)$ between the most symmetric arrangement of the crystal structure. Their length $a_{\mathrm{T}}, b_{\mathrm{T}}, c_{\mathrm{T}}$, should correspond to the minimal distances between the heavy fragments in the crystal structure (Table 1). Detailed mathematics behind the technique can be found in [34-36]. Finally, the shortest sublattice should be found with the corresponding angles close to $60^{\circ}, 90^{\circ}, 109.5^{\circ}$, and $120^{\circ}$, which is usually a sign for the most symmetric sub-cells. Orientation of pseudo-translational sub-lattices should correspond to the layers with the highest packing density in the crystal structure.

Among all crystal structures, only $\left(\mathrm{NH}_{4}\right)_{3}\left[\mathrm{RhCl}_{6}\right] \cdot \mathrm{H}_{2} \mathrm{O}$ corresponds to the hexagonal closed packed lattice of $\left[\mathrm{RhCl}_{6}\right]^{3-}$ anions, with hexagonal layers arranged with $A B$ stacking perpendicular to the $a$-direction in the crystal structure. Distances between the layers correspond to $a_{\mathrm{T}}=7.01 \AA$ (Figure 2). Two ammonia cations occupy tetrahedral voids in the packing. Crystal water and the third ammonia cation corresponds to the octahedral positions of the packing. Water-free $\left(\mathrm{NH}_{4}\right)_{3}\left[\mathrm{RhCl}_{6}\right]$ seems to be isostructural to $\left(\mathrm{NH}_{4}\right)_{3}\left[\mathrm{IrCl}_{6}\right]$ [30]. In the crystal structure of $\left(\mathrm{NH}_{4}\right)_{3}\left[\mathrm{IrCl}_{6}\right]$, translational sublattice correspond to ideal pseudo-rhombohedral sub-cells with angles close to $\alpha_{\mathrm{T}} \approx 60.3^{\circ}$ and three nearly equal axis of $7.32 \AA$. Such an arrangement correspond to the face-centered cubic packings of three hexagonal layers with $A B C$ stackings. Ammonia occupy all tetragonal and all hexagonal voids in the structure.

In the crystal structure of fac- $\left[\mathrm{Rh}\left(\mathrm{NH}_{3}\right)_{3} \mathrm{Cl}_{3}\right]$, the hexagonal layers of isolated fac- $\left[\mathrm{Rh}\left(\mathrm{NH}_{3}\right)_{3} \mathrm{Cl}_{3}\right]$ octahedrons was observed, perpendicular to the $c$-direction (Figure 4). The shortest distances between the octahedrons in the layers corresponded to $a_{\mathrm{T}}=b_{\mathrm{T}}=5.94 \AA$. Hexagonal layers formed quite unusual $A A$ stacking along the $c$-direction, which could be driven by the interactions between the triangle \{ ... . $\left.\left[\left(\mathrm{NH}_{3}\right)_{3} \mathrm{RhCl}_{3}\right] \ldots\left[\left(\mathrm{NH}_{3}\right)_{3} \mathrm{RhCl}_{3}\right] \ldots\right\}$ faces (Figure 4, left).

In all other structures, the metrics obtained corresponded to the pseudo-rhombohedral sub-cells with angles close to $\alpha_{\mathrm{T}} \approx 60-70^{\circ}$ and two nearly equal longer axis (6.90-7.30 $\AA$ ) and one shorter axis (6.40-7.10 $\AA$ ). Such an arrangement corresponded to the face-centered cubic packings of three hexagonal layers with $A B C$ stackings. As an example, the correspondence of closed-packed layers and pseudo-rhombohedral sub-cell for $\left(\mathrm{NH}_{4}\right)_{2}\left[\mathrm{Rh}\left(\mathrm{NH}_{3}\right) \mathrm{Cl}_{5}\right]$ is shown in Figure 2. In the crystal structures of $\left(\mathrm{NH}_{4}\right)_{2}\left[\mathrm{Rh}\left(\mathrm{NH}_{3}\right) \mathrm{Cl}_{5}\right]$, trans- $\left[\mathrm{Rh}\left(\mathrm{NH}_{3}\right)_{4} \mathrm{Cl}_{2}\right] \mathrm{Cl} \cdot \mathrm{H}_{2} \mathrm{O}$, $\left[\mathrm{Rh}\left(\mathrm{NH}_{3}\right)_{5} \mathrm{Cl} \mathrm{Cl}_{2}\right.$, and $\left[\mathrm{Rh}\left(\mathrm{NH}_{3}\right)_{6}\right] \mathrm{Cl}_{3}$, the hexagonal layers corresponded to the packings of the coordination ions, ammonia in $\left(\mathrm{NH}_{4}\right)_{2}\left[\mathrm{Rh}\left(\mathrm{NH}_{3}\right) \mathrm{Cl}_{5}\right]$ could be found in the tetrahedral voids; coordinated ammonia 
was placed in the octahedral voids of the closed-packed structure. $\mathrm{Cl}^{-}$in the crystal structure of $\left[\mathrm{Rh}\left(\mathrm{NH}_{3}\right)_{5} \mathrm{Cl}\right] \mathrm{Cl}_{2}$ was located in the tetrahedral voids and coordinated $\mathrm{Cl}$ was placed in the octahedral voids of the packing. Similar, $\mathrm{Cl}^{-}$anions in trans- $\left[\mathrm{Rh}\left(\mathrm{NH}_{3}\right)_{4} \mathrm{Cl}_{2}\right] \mathrm{Cl}_{2} \cdot \mathrm{H}_{2} \mathrm{O}$ could be found in the tetrahedral voids, crystal water was located in the octahedral positions of the packing. In $\left[\mathrm{Rh}_{(}\left(\mathrm{NH}_{3}\right)_{6}\right] \mathrm{Cl}_{3}$, two $\mathrm{Cl}^{-}$anions were located in the tetragonal voids, one $\mathrm{Cl}^{-}$anion corresponded to the octahedral void in the $A B C$ packing of $\left.\left[\mathrm{Rh}_{(} \mathrm{NH}_{3}\right)_{6}\right]^{3+}$ cations.
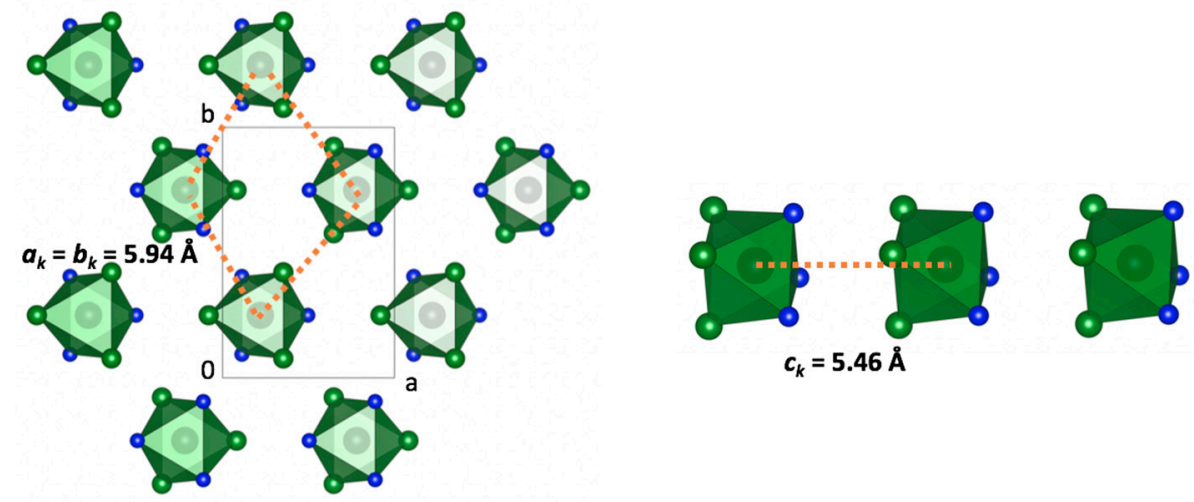

Figure 4. Left: crystal structure of fac- $\left[\mathrm{Rh}\left(\mathrm{NH}_{3}\right)_{3} \mathrm{Cl}_{3}\right]$ [4] along the $c$-direction ( $\mathrm{Rh}$ atoms are shown as black circles, nitrogen atoms are blue, chlorine atoms are green, and the hydrogen atoms are omitted for clarity); right: stacking of fac- $\left[\mathrm{Rh}\left(\mathrm{NH}_{3}\right)_{3} \mathrm{Cl}_{3}\right]$ octahedrons parallel to the $c$-direction. Dotted lines show pseudo-trigonal sub-cell.

The crystal structure of cis- $\left[\mathrm{Rh}\left(\mathrm{NH}_{3}\right)_{4} \mathrm{Cl}_{2}\right] \mathrm{Cl}$ showed a relatively low packing density, where the hexagonal layers had empty space. $\mathrm{Cl}^{-}$anions occupied hexagonal voids in the structure. N ... $\mathrm{Cl}$ interactions between the $\mathrm{cis}-\left[\mathrm{Rh}\left(\mathrm{NH}_{3}\right)_{4} \mathrm{Cl}_{2}\right]^{+}$cations should be mentioned. The structure had a hexagonal sublattice with angles $\alpha_{\mathrm{T}}=\beta_{\mathrm{T}}=60.1^{\circ}, \gamma_{\mathrm{T}}=120^{\circ}$. The shortest pseudo-translational vector, $c_{\mathrm{T}}=6.87 \AA$, corresponded to the distances between the pseudo-hexagonal layers.

\section{Conclusions}

$\mathrm{Rh}(\mathrm{III})$ is known as a metal with rich coordination chemistry in solution and in solid-state. In the last decade, nearly all possible octahedral $\mathrm{Rh}(\mathrm{III})$ chloroamine complexes were synthesized and structurally characterized. Some rare compounds were prepared just recently. Synthetic procedures available in the $\mathrm{Rh}(\mathrm{III})$ chemistry included direct substitution of $\mathrm{Cl}^{-}$to $\mathrm{NH}_{3}$ in solution, as well as catalytic reactions. In some cases, $\mathrm{NO}_{2}{ }^{-}-$and $\mathrm{C}_{2} \mathrm{O}_{4}{ }^{2-}$-coordinated derivatives could be used as intermediates. Such approaches were never successful in $\operatorname{Ir}(\mathrm{III})$ chemistry, where only the direct substitution can be applied. For synthesis of $\mathrm{Pt}(\mathrm{IV})$, oxidation of the $\mathrm{Pt}(\mathrm{II})$ species with $\mathrm{Cl}_{2}$ in the solution is typical. Such routes are impossible in Rh(III) chemistry.

Synthetic and crystal chemistry of $\mathrm{Cr}(\mathrm{III}), \mathrm{Co}(\mathrm{III}), \operatorname{Pt}(\mathrm{IV}), \operatorname{Ir}(\mathrm{III})$, and $\operatorname{Ir}(\mathrm{IV})$ compounds have been investigated in many details; nevertheless, only $\left[\mathrm{Rh}\left(\mathrm{NH}_{3}\right)_{x} \mathrm{Cl}_{1-x}\right]$ complexes containing $\mathrm{Rh}(\mathrm{III})$ give a nearly complete series available for detailed systematic analysis of their transformations and details of their crystal chemistry. For iridium, the existence of $\operatorname{Ir}(\mathrm{III})$ and $\operatorname{Ir}(\mathrm{IV})$ complexes with identical coordination spheres was experimentally confirmed. $\left[\mathrm{IrCl}_{6}\right]^{3-}$ and $\left[\mathrm{IrCl}_{6}\right]^{2-}$, as well as pairs of $\left[\operatorname{Ir}\left(\mathrm{NH}_{3}\right) \mathrm{Cl}_{5}\right]^{2-} /\left[\operatorname{Ir}\left(\mathrm{NH}_{3}\right) \mathrm{Cl}_{5}\right]^{-}$and $\left[\operatorname{Ir}\left(\mathrm{NH}_{3}\right)_{4} \mathrm{Cl}_{2}\right]^{2+} /\left[\operatorname{Ir}\left(\mathrm{NH}_{3}\right)_{4} \mathrm{Cl}_{2}\right]^{+}$with $\operatorname{Ir}(\mathrm{III})$ and $\operatorname{Ir}(\mathrm{IV})$, respectively, were available for investigation [31]. Among all $\mathrm{Rh}(\mathrm{III})\left[\mathrm{Rh}\left(\mathrm{NH}_{3}\right)_{x} \mathrm{Cl}_{1-x}\right]$ complexes only mer-[ $\left[\mathrm{Rh}\left(\mathrm{NH}_{3}\right)_{3} \mathrm{Cl}_{3}\right]$ was not described in the literature; further efforts to synthetize and characterize such coordination compounds should be made.

$\left[\mathrm{Rh}\left(\mathrm{NH}_{3}\right)_{x} \mathrm{Cl}_{1-x}\right]$ complexes did not show a large variety in their crystal structures. All crystal structures could be described to have a closed-packing coordination of ions, with the contra-ions and crystal water located in octahedral or tetrahedral voids. $\left(\mathrm{NH}_{4}\right)_{3}\left[\mathrm{RhCl}_{6}\right] \cdot \mathrm{H}_{2} \mathrm{O}$ showed hexagonal closed-packed structure, fac- $\left[\mathrm{Rh}\left(\mathrm{NH}_{3}\right)_{3} \mathrm{Cl}_{3}\right]$ showed a relatively rare, one-layer packing due to the 
formation of specific contacts between non charged fac- $\left[\mathrm{Rh}\left(\mathrm{NH}_{3}\right)_{3} \mathrm{Cl}_{3}\right]$ octahedrons. Such one-layer packing might be stable only under curtain $P-T$ conditions and small changes in pressure or temperature, as well as crystallization from other solvents might be revealed in the formation of other polymorphic modifications of fac- $\left[\mathrm{Rh}\left(\mathrm{NH}_{3}\right)_{3} \mathrm{Cl}_{3}\right]$, similar to several known polymorphic modifications isolated for fac- $-\left[\mathrm{Rh}\left(\mathrm{NH}_{3}\right)_{3}\left(\mathrm{NO}_{2}\right)_{3}\right]$.

The crystal structures of $\left(\mathrm{NH}_{4}\right)_{2}\left[\mathrm{Rh}\left(\mathrm{NH}_{3}\right) \mathrm{Cl}_{5}\right]$, trans- $\left[\mathrm{Rh}\left(\mathrm{NH}_{3}\right)_{4} \mathrm{Cl}_{2}\right] \mathrm{Cl} \cdot \mathrm{H}_{2} \mathrm{O}$, $\left[\mathrm{Rh}\left(\mathrm{NH}_{3}\right)_{5} \mathrm{Cl}\right] \mathrm{Cl}_{2}$, and $\left[\mathrm{Rh}\left(\mathrm{NH}_{3}\right)_{6}\right] \mathrm{Cl}_{3}$ had face-centered cubic arrangement of closed, packed hexagonal layers. Such an arrangement could be easily found, based on pseudo-translational sublattices. In all mentioned salts, pseudo-translational sublattices had similar metrics. Directions of pseudo-translational vectors gave the orientation of the closed-packed layers in their crystal structures. It is important to note that the crystal structures of $\left(\mathrm{NH}_{4}\right)_{2}\left[\mathrm{Rh}\left(\mathrm{NH}_{3}\right) \mathrm{Cl}_{5}\right]$ and $\left[\mathrm{Rh}\left(\mathrm{NH}_{3}\right)_{5} \mathrm{Cl}\right] \mathrm{Cl}_{2}$ were similar. It is possible that this is a general tendency in coordination chemistry, which should be proven for other classes of isoformular coordination compounds. Such a phenomenon might be useful as a tool for crystal structure prediction and preparation of double complexes.

The $\mathrm{Rh}(\mathrm{III})$ chloroamine complexes did not realize the maximal possible symmetry of coordination polyhedrons. Deformations of the coordination polyhedrons depended not only on the ligand arrangements, but also possibly on the packings of deformed octahedrons in the crystal structures. Closed-packings are typical for such structurally rigid coordination species, but local structure and symmetry of coordination polyhedrons usually fit the packings of hexagonal packed layers. Changes in the interatomic distances were also high due to trans-effect in cis- and trans-isomers. If specific interactions could be realized in the crystal structures (similar to fac- $\left[\mathrm{Rh}\left(\mathrm{NH}_{3}\right)_{3} \mathrm{Cl}_{3}\right]$ ) due to sterically-driven factors, then close-packed arrangements could possibly distort with a formation of other types of crystal packings.

Author Contributions: Conceptualization, K.V.Y. and S.A.G.; Material Synthesis, K.V.Y.; X-ray diffraction experiments, A.S.S. and W.K.; all authors contributed to writing and editing manuscript. All authors have read and agreed to the published version of the manuscript.

Funding: This research received no external funding

Acknowledgments: Egor K. Yusenko (Pascal Gymnasium, Münster) is thanked for his help with the synthesis of Rh salts and growing their single crystals; Dr. Jana Falkenhagen and Max Rothenberg (BAM) are thanked for the measurements of the IR spectra; Dr. Kerstin Scheurell (BAM) is thanked for the collection of Raman spectra.

Conflicts of Interest: The authors declare no conflict of interest.

\section{References}

1. Yao, Z.J.; Deng, W. Half-sandwich late transition metal complexes based on functionalized carborane ligands. Coord. Chem. Rev. 2016, 309, 21-35. [CrossRef]

2. Yao, Z.J.; Li, K.; Zhang, J.Y.; Deng, W. [NO]- and [NN]-coordination mode rhodium complexes based on a flexible ligand: Synthesis, reactivity and catalytic activity. New J. Chem. 2016, 40, 8753-8759. [CrossRef]

3. Lebedinskii, V.V. About rhodium amine complexes. Izv. Sektora Platiny i Drug. Blagorodn. Met. (in Russ.) $1935,12,67-77$.

4. Jörgensen, S.M. Beiträge zur Chemie der Rhodiumammoniakverbindungen. J. Pract. Chemie 1883, 27, 433-489. [CrossRef]

5. West, C.D. Crystal Structure of $\left.\mathrm{Rh}\left(\mathrm{NH}_{3}\right)_{5} \mathrm{Cl}\right) \mathrm{Cl}_{2}$. Z. Kristallographie 1935, 91, 181-186. [CrossRef]

6. Vasiliev, A.D.; Molokeev, M.S.; Baidina, I.A.; Belyaev, A.V.; Vorob'eva, S.N. Arrangement of Rh ${ }^{3+}$ ions in fac-triamminetrichloridorhodium from powder data and in fac-triamminetrinitratorhodium crystals twinned by merohedry. Acta Cryst. C 2013, 69, 1462-1466. [CrossRef]

7. Khranenko, S.P.; Bykova, E.A.; Alexeyev, A.V.; Tyutyunnik, A.P.; Gromilov, S.A. Complex salts with participation of $\left[\mathrm{Rh}\left(\mathrm{NH}_{3}\right)_{6}\right]^{3+}$ cation. J. Struct. Chem. 2012, 53, 521-526. [CrossRef]

8. Baidina, I.A.; Belyaev, A.V.; Korolkov, I.V.; Smolentzev, A.I.; Vorob'eva, S.N. Synthesis and crystal structure of chlorocomplexes of diamino and monoamino Rh(III). J. Struct. Chem. 2019, 60, 1543-1549. [CrossRef] 
9. Bokii, G.B. Crystal chemistry of Pt(IV) amines. Izv. Akad. Nauk SSSR, Ser. Fiz. Nauk (in Russ.) 1951, 15, 170-175.

10. Podberezskaya, N.V.; Yudanova, T.S.; Magarill, S.A.; Ipatova, E.N.; Romanenko, G.V.; Pervukhina, N.V.; Borisov, S.V. Structures of crystals of inorganic coordination compounds with $\left[M A_{5} \mathrm{X}\right]$ and $\left[M X_{5} A\right]$ complex ions containing neutral $(A)$ and acidic $(X)$ ligands at very high packing densities. J. Struct. Chem. 1991, 32, 894-904. [CrossRef]

11. Peshchevitskii, B.I.; Beliaev, A.V.; Dvurechenskaia, S.I. Synthesis of rhodium tetraamines. Izv. Sib. Otd. Akad. Nauk SSSR, Ser. Khim. Nauk (in Russ.) 1972, 4, 138-139.

12. Poë, A.J.; Twigg, M.V. Synthesis and kinetic behaviour of some trans-diacidotetraamminerhodium(III) complexes. Can. J. Chem. 1972, 50, 1089-1092.

13. Hancock, M.P. Synthesis and characterisation of cis-tetraamminerhodium(III). Acta Chem. Scand. A 1975, 29, 468-474.

14. Dvurechenskaia, S.I.; Beliaev, A.V.; Peshchevitskii, B.I. The acid properties investigation of some rhodium(III). Izv. Sib. Otd. Akad. Nauk SSSR, Ser. Khim. Nauk (in Russ.) 1973, 4, 49-53.

15. Fergusson, J.E.; Sherlock, R.R. Structural and spectral studies of halogeno complexes of rhodium(III). Aust. J. Chem. 1977, 30, 1445-1460.

16. Bukanova, A.E.; Sergienko, V.S.; Sidorova, T.P.; Belan, V.N.; Shubochkin, L.K. Preparation and crystal structure of $\left(\mathrm{NH}_{4}\right)_{3}\left[\mathrm{RhCl}_{6}\right] \cdot \mathrm{H}_{2} \mathrm{O}$, a product of the reaction of rhodium chloride with L-aspargine. Russ. J. Inorg. Chem. 1988, 33, 379-382.

17. Treiber, U.; Zwilling, M.; Schweda, E.; Strähle, J. Die Chloro-rhodate(III) $\left[\mathrm{RhCl}_{6}\right]^{3-}$ und $\left[\mathrm{RhCl}_{5}\left(\mathrm{H}_{2} \mathrm{O}\right)\right]^{2-}$. Kristallstruktur von $\left(\mathrm{NH}_{4}\right)_{3}\left[\mathrm{RhCl}_{6}\right] \cdot \mathrm{H}_{2} \mathrm{O}$. Z. Naturforsch. B 1986, 41, 1-3. [CrossRef]

18. Lebedinskii, V.V. New rhodium amine complexes. Izv. Sektora Platiny i Drug. Blagorodn. Met. (in Russ.) 1933, 11, 3-12.

19. Khranenko, S.P.; Baidina, I.A.; Gromilov, S.A.; Belyaev, A.V. Synthesis and crystal structure of trinitritriamminerhodium(III) [ $\left.\mathrm{Rh}\left(\mathrm{NO}_{2}\right)_{3}\left(\mathrm{NH}_{3}\right)_{3}\right]$. J. Struct. Chem. 2002, 43, 142-146. [CrossRef]

20. Jonson, S.A.; Basolo, F. Synthesis and characterization of some diacidotetraamrninerhodium(III) compounds. Inorg. Chem. 1962, 1, 925-932. [CrossRef]

21. Hancock, M.P.; Skibsted, L.H. Rhodium(III) complexes of the trans-tetraammine series. Synthesis and purification. Acta Chem. Scand. A 1984, 38, 87-90. [CrossRef]

22. Korenev, S.V.; Venediktov, A.B.; Yusenko, K.V.; Shubin, Y.V. Synthesis and properties of $\left[\mathrm{Rh}\left(\mathrm{NH}_{3}\right)_{5} \mathrm{Cl}\right]\left[\mathrm{PtCl}_{4}\right]$. Russ. J. Coord. Chem. 2000, 26, 358-360.

23. Bykov, M.; Yusenko, K.V.; Bykova, E.; Pakhomova, A.; Kraus, W.; Dubrovinskaia, N.; Dubrovinsky, L. Synthesis of arsenopyrite-type rhodium pernitride $\mathrm{RhN}_{2}$ from a single-source azide precursor. Eur. J. Inorg. Chem. 2019, 2019, 3667-3671. [CrossRef]

24. Bee, M.V.; Kettle, S.F.A.; Powell, D.B. Vibrational spectra of ruthenium, rhodium, osmium and iridium acidopentammines. Spectrochim Acta Part A Mol. Biomol. Spectrosc. 1974, A30, 139-150. [CrossRef]

25. Schmidt, K.H.; Müller, A. Skeletal vibrational spectra, force constants, and bond properties of transition metal ammine complexes. Inorg. Chem. 1975, 14, 2183-2187. [CrossRef]

26. Sheldrick, G.M. Crystal structure refinement with SHELXL. Acta Crystallogr. Sect. C 2015, 71, 3-8. [CrossRef]

27. Baidina, I.A.; Podberezskaya, N.V.; Solov'yova, L.P. Crystal structure of trans-tetraminechloriderhodium(III) trans-[Rh $\left.\left(\mathrm{NH}_{3}\right)_{4} \mathrm{Cl}_{2}\right]$ Cl. J. Struct. Chem. 1974, 5, 940-941.

28. Rankin, D.A.; Penfold, B.R.; Fergusson, J.E. The chloro and bromo complexes of Ir(III) and Ir(IV). II* Structural chemistry of IrIII complexes. Aust. J. Chem. 1983, 36, 871-883. [CrossRef]

29. Evans, R.S.; Hopcus, E.A.; Bordner, J.; Schreiner, A.F. Molecular and crystal structures of halopentaamminerhodium(III) complexes, $\left[\mathrm{Rh}\left(\mathrm{NH}_{3}\right)_{5} \mathrm{Cl}\right] \mathrm{Cl}_{2}$ and $\left[\mathrm{Rh}\left(\mathrm{NH}_{3}\right)_{5} \mathrm{Br}_{\mathrm{B}} \mathrm{Br}_{2}\right.$. J. Cryst. Mol. Struct. 1973, 3, 235-245. [CrossRef]

30. Weishaupt, M.; Bezler, H.; Strähle, J. Darstellung und Kristallstruktur von $\left(\mathrm{NH}_{4}\right)_{2}\left[\mathrm{~V}\left(\mathrm{NH}_{3}\right) \mathrm{Cl}_{5}\right]$. Die Kristallchemie der Salze $\left(\mathrm{NH}_{4}\right)_{2}\left[\mathrm{~V}\left(\mathrm{NH}_{3}\right) \mathrm{Cl}_{5}\right]$, $\left[\mathrm{Rh}\left(\mathrm{NH}_{3}\right)_{5} \mathrm{Cl}\right] \mathrm{Cl}_{2}$ und $\mathrm{M}_{2} \mathrm{VXCl}_{5}$ mit $\mathrm{M}=\mathrm{K}, \mathrm{NH}_{4}, \mathrm{Rb}, \mathrm{Cs}$ und $\mathrm{X}=\mathrm{Cl}$, O.Z. Anorg. Allg. Chem. 1978, 440, 52-64. [CrossRef]

31. Deflon, V.M.; Mössmer, C.M.; Strähle, J. Synthese und Struktur von Ammin- und Amidokomplexen des Iridiums. Z. Anorg. Allg. Chem. 1999, 625, 2186-2191. [CrossRef] 
32. Korenev, S.V.; Venediktov, A.B.; Shubin, Y.V.; Gromilov, S.A.; Yusenko, K.V. Synthesis and structure of binary complexes of platinum group metals - precursors of metallic materials. J. Struct. Chem. 2003, 44, 46-59. [CrossRef]

33. Gromilov, S.A.; Korenev, S.V.; Baidina, I.A.; Korolkov, I.V.; Yusenko, K.V. Syntheses of $\left[\mathrm{Rh}\left(\mathrm{NH}_{3}\right)_{5} \mathrm{Cl}\right]\left[\mathrm{MCl}_{6}\right]$ $(M=\mathrm{Re}, \mathrm{Os}, \mathrm{Ir})$ and investigation of their thermolysis products. Crystal structure of $\left.\left[\mathrm{Rh}_{(} \mathrm{NH}_{3}\right)_{5} \mathrm{Cl}\right]\left[\mathrm{OsCl}_{6}\right]$. J. Struct. Chem. 2003, 43, 488-494. [CrossRef]

34. Gromilov, S.A.; Bykova, E.A.; Borisov, S.V. Algorithms, software, and examples of pseudotranslational sublattice analysis for crystal structures. Cryst. Rep. 2011, 56, 947-952. [CrossRef]

35. Borisov, S.V. Cation sublattices in inorganic compounds. J. Struct. Chem. 1986, 27, 486-488. [CrossRef]

36. Gromilov, S.A.; Borisov, S.V. Using pseudoperiodicity for polycrystal XRD determination of the general structural motif of coordination compounds. J. Struct. Chem. 2003, 44, 664-680. [CrossRef]

Sample Availability: Samples of the compounds $\left(\mathrm{NH}_{4}\right)_{2}\left[\mathrm{Rh}\left(\mathrm{NH}_{3}\right) \mathrm{Cl}_{5}\right]$, trans- $\left[\mathrm{Rh}\left(\mathrm{NH}_{3}\right)_{4} \mathrm{Cl}_{2}\right] \mathrm{Cl} \cdot \mathrm{H}_{2} \mathrm{O}$, $\left[\mathrm{Rh}\left(\mathrm{NH}_{3}\right)_{5} \mathrm{Cl}\right] \mathrm{Cl}_{2}$, cis- $\left[\mathrm{Rh}\left(\mathrm{NH}_{3}\right)_{4} \mathrm{Cl}_{2}\right] \mathrm{Cl}$, and $\left[\mathrm{Rh}\left(\mathrm{NH}_{3}\right)_{6}\right] \mathrm{Cl}_{3}$ are available from the authors.

(C) 2020 by the authors. Licensee MDPI, Basel, Switzerland. This article is an open access article distributed under the terms and conditions of the Creative Commons Attribution (CC BY) license (http://creativecommons.org/licenses/by/4.0/). 